\author{
مقايسه عملكرد مدلهاى خطى تعميميافته، جنگل تصادفى و درخت گر اديان بوستينگ در \\ بر آورد تبخير - تعرق گياه مرجع (مطالعه موردى: دشت سيستان) \\ هادى سياسر "، تورج هنر ' و محمد عبداللهى بور

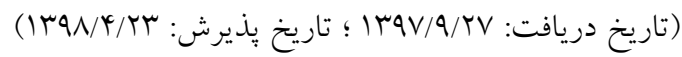

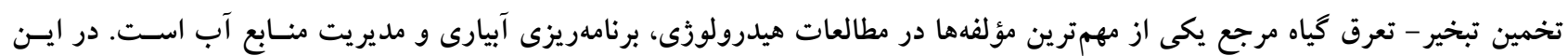

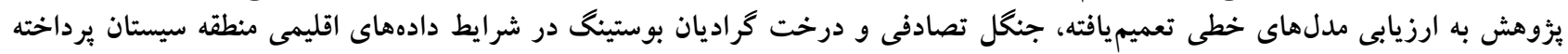

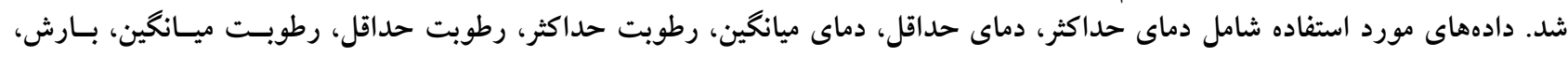

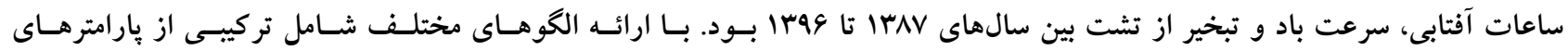

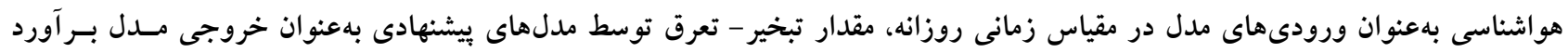

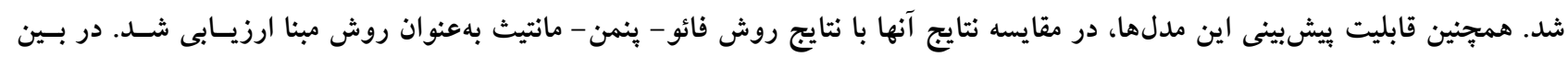

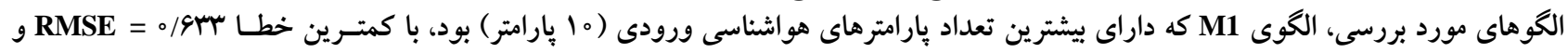

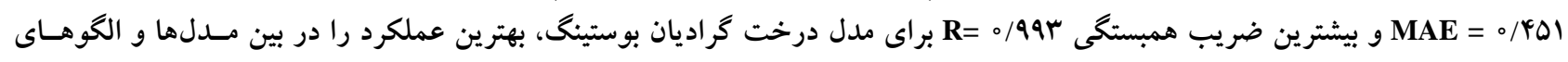

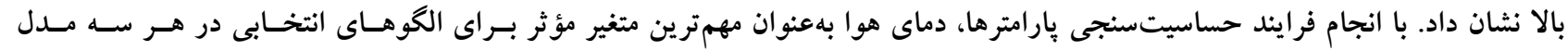

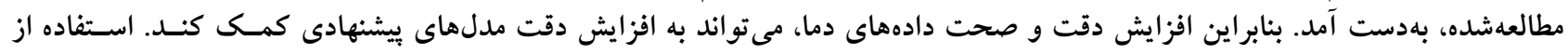

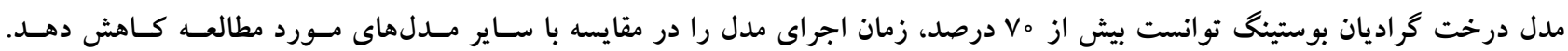

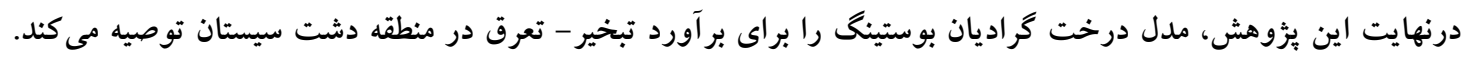

وازههاى كليدى: روش فائو - بنمن - مانتيث، بارامترهاى هواشناسى، حساسيتسنجى، دماى هوا

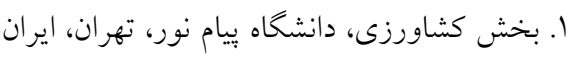

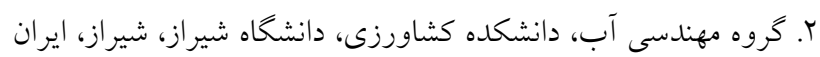

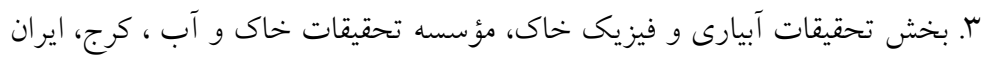

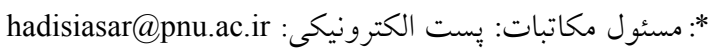


از روش فائو - هينمن - مانتيث بهعنوان روش مبنا براى ارزيابىها استفاده شد. مهمترين جالش در روش فائو - هينمن - مانتيث، نياز

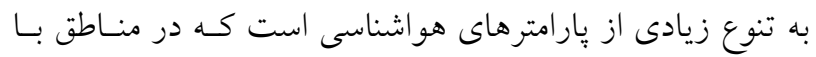

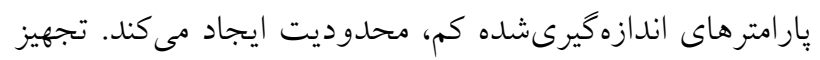

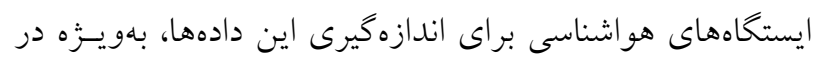

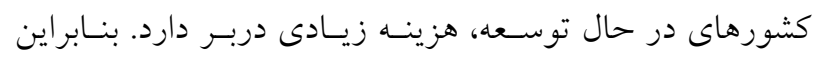

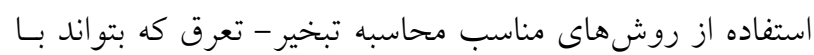

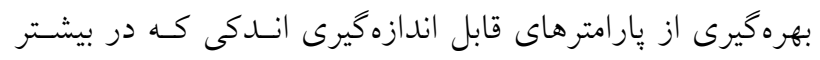

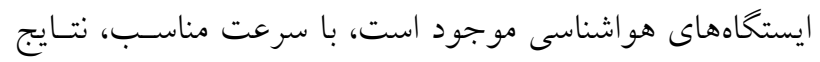

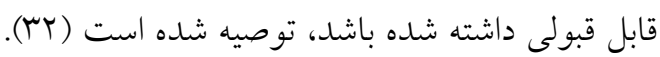

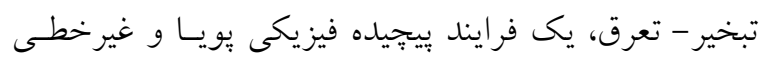

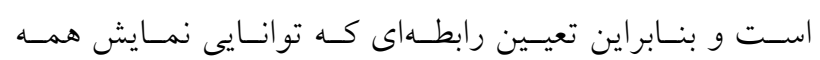

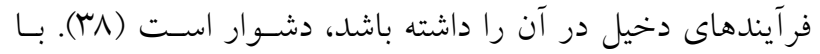

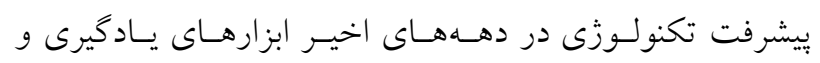
روشهاى نوين هوشمند، براى حل برخسى از مشـكلات، ارائسه

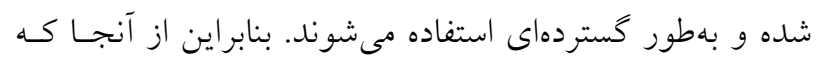
روش شبكههاى عصبى مصنوعى بهعنوان يـك ابـزار هوشـمند

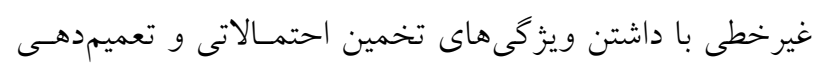

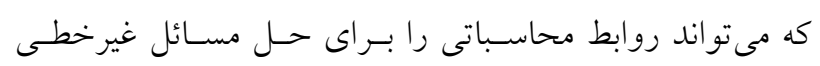

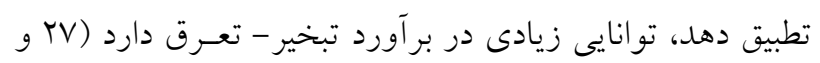

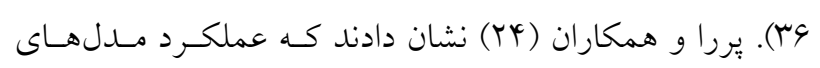

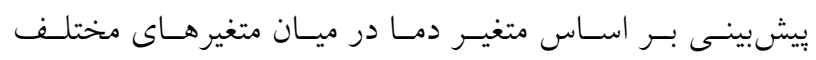

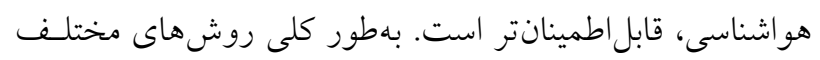

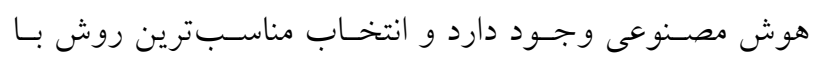
بهترين عملكرد ضرورى است.

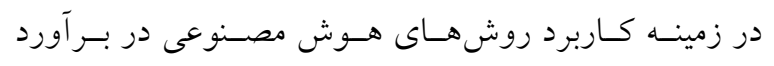

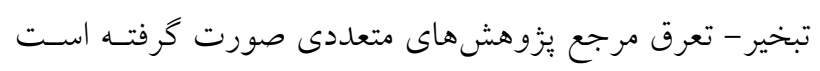

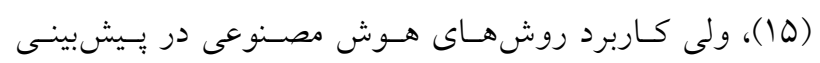

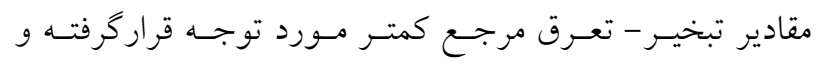

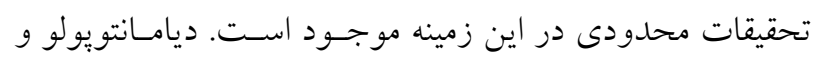

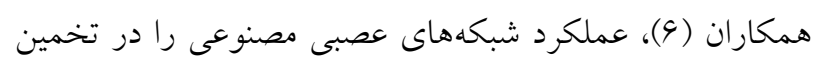

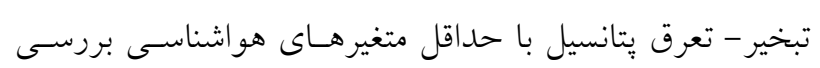

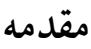
ايران كشورى با اقليم خشك و نيمهخشـى از توزيـع نامناسـب مانب زمانى و مكانى بارشهـاى جـوى برخسوردار اسـت. در خنسين

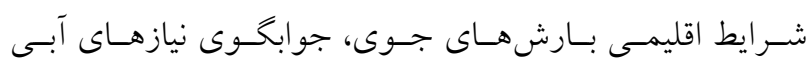

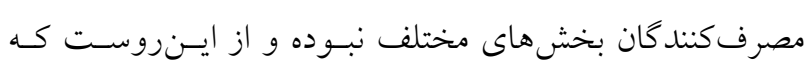

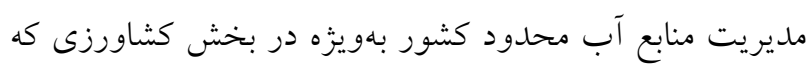

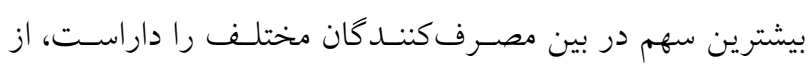
دغدغههاى اصلى مديران بخش آب و كشاورزى كشـور اسـت.

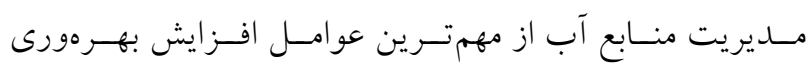
اقتصادى در بخش كشـاورزى محسـوب مسىشـود. در شـرايط

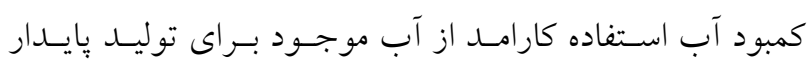

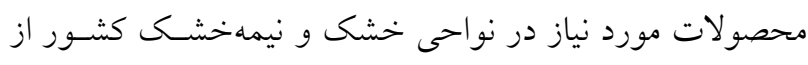

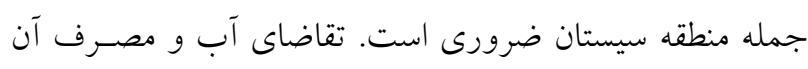

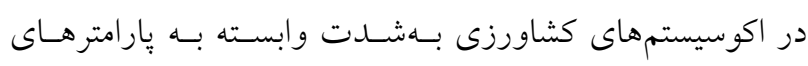

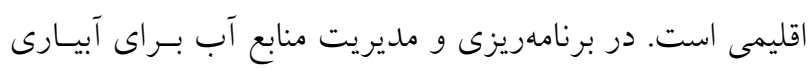

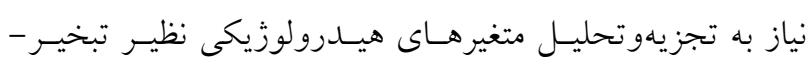
تعرق وجود دارد. مطالعات زيادى براى تخمين مقدار تبخير - تعرق با اسـتفاده

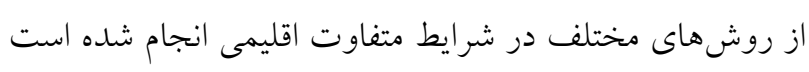

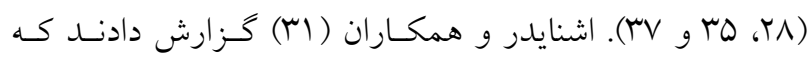

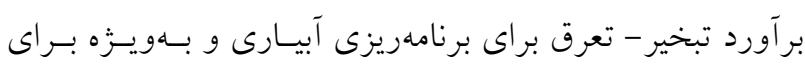

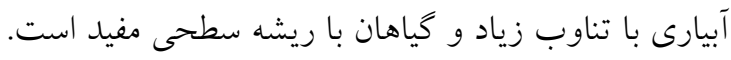

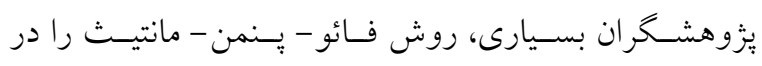

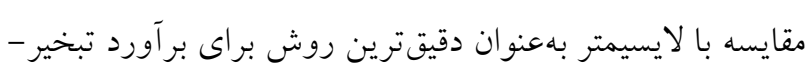

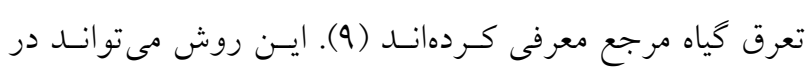

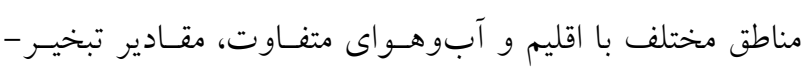
تعرق قابل اعتمادى ارائه دهد (Tr). دهقانى سـانيج و همكـاران

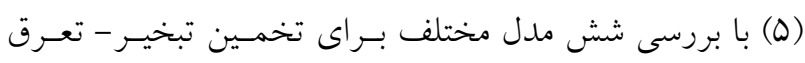

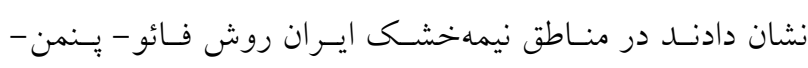

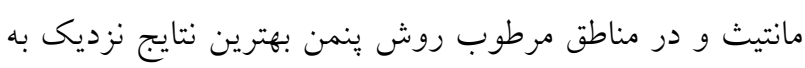
نتايج لايسيمتر را ارائه مى كند.

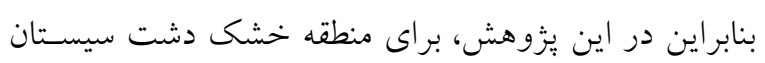


را در بــرآورد تبخيـر - تعـرق در شـرايط محســوديت دادههـاى

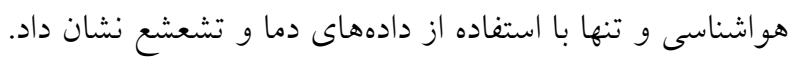
در يزوهشى در سارى بهمنظور دستيابى به تخمين تبخير - تعرق

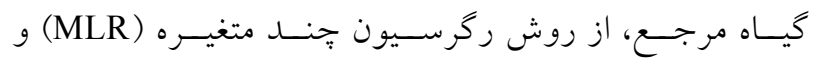

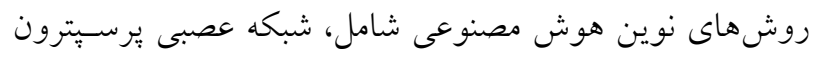

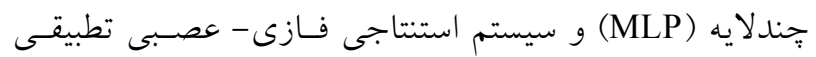
(Adaptive Neuro-Fuzzy Inference System ،ANFIS) استفاده شد. نتايج يزوهش نشان داد زمانى كه از جهار :ـارامتر

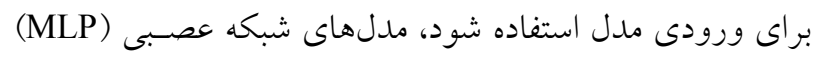

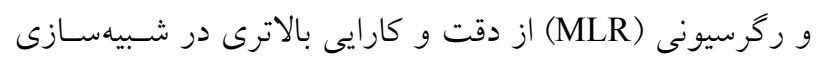

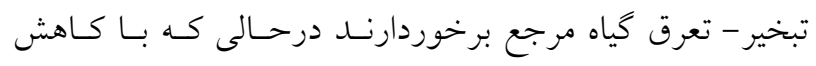
קارامتر ورودى به سه و يا كمتر، مدل شسبكه عصسبى (ANFIS)

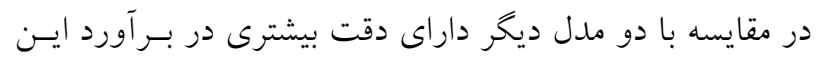
يارامتر مهم اقليمى بود (19).

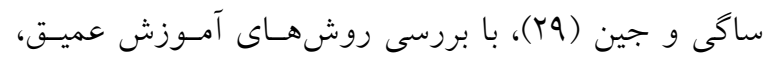

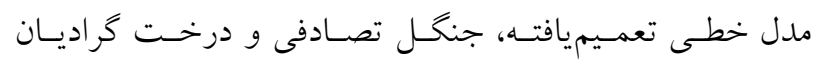

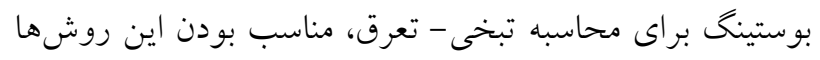

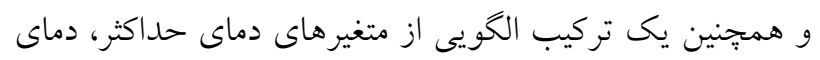

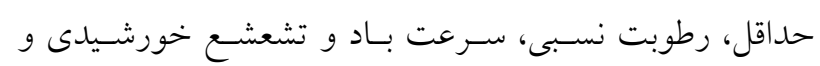

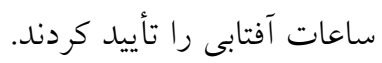

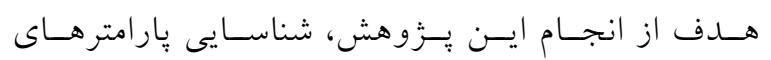

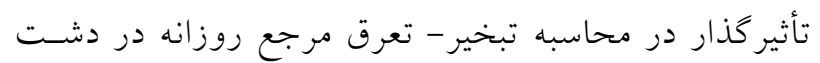

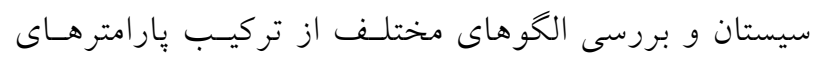

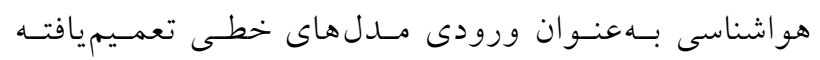
(Generalized Linear Model ،GLM)

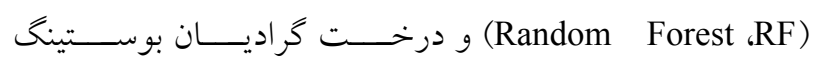
بهنوان تكنيكهاى نـوين (Gradient Boosting Trees ،GBT) محاسباتى و انتخاب مدل برتر بر اساس الخوى منتخب است.

\section{مواد و روشها - ماد} دشـت سيسـتان در شـمال اسـتان سيسـتان و بلوجسـتان و در

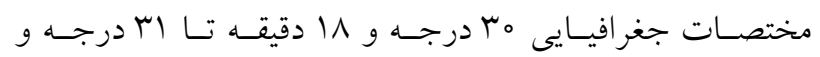

كردند. آنها در بررسى خود از دادههـاى يـك ايستيخاه خودكـار

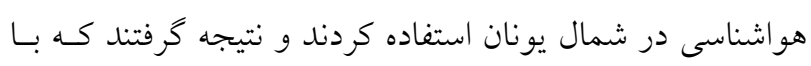

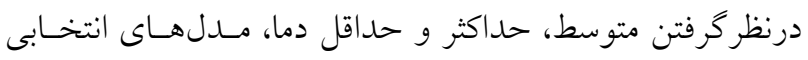

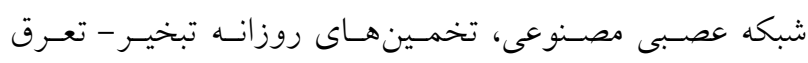

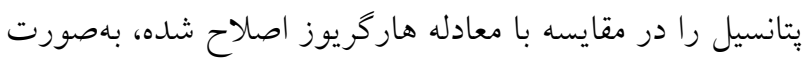

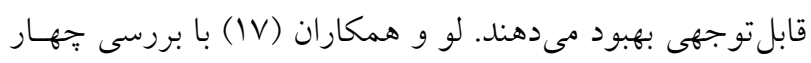

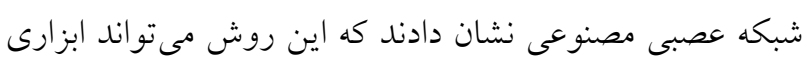
مناسب براى ييشبينى تبخير - تعرق باشد. مطابق تحقيقات آنها،

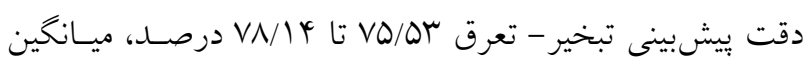

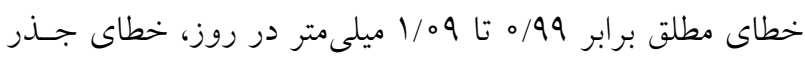

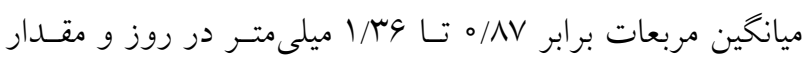
ضريب همبستخى بين V/。 تا VD/ محاسبه شد.

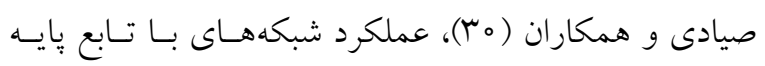
شــاعى (Radial Basis Function, RBF) و شــبكههاى

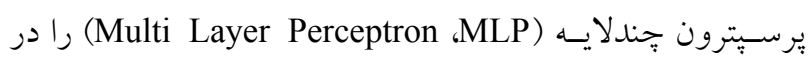

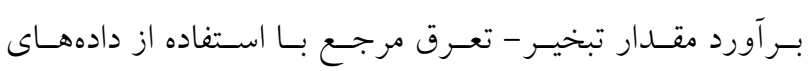

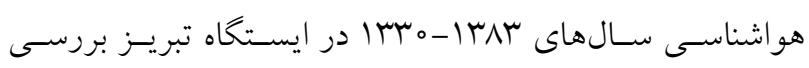

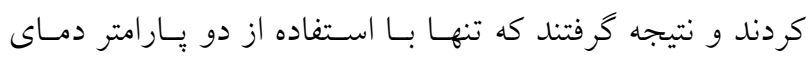

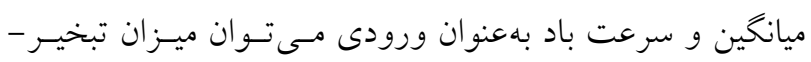

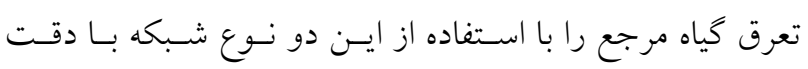

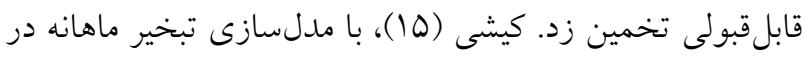

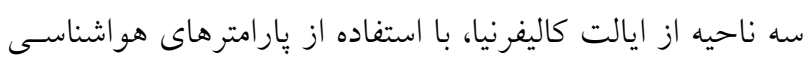

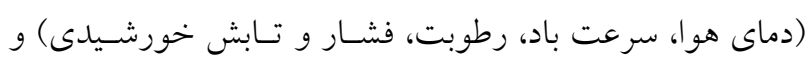
روش شبكه عصبى مصنوعى، تبخير را برآورد كردند. نتايج آنها

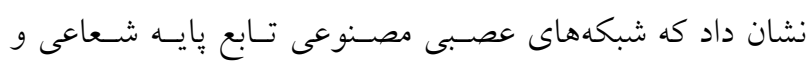

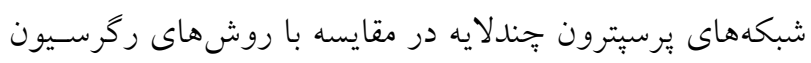

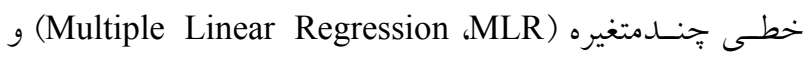
Stewart-Stephens كارايى و دقت بالاترى برخوردار است. جين و همكـاران (1/)،

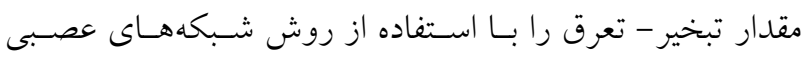

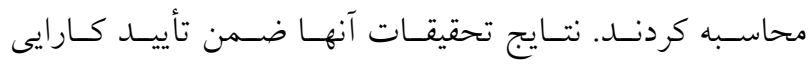
شبكهاى عصبى در تخمين اين بديده، دقت مناسب ايسن روش 

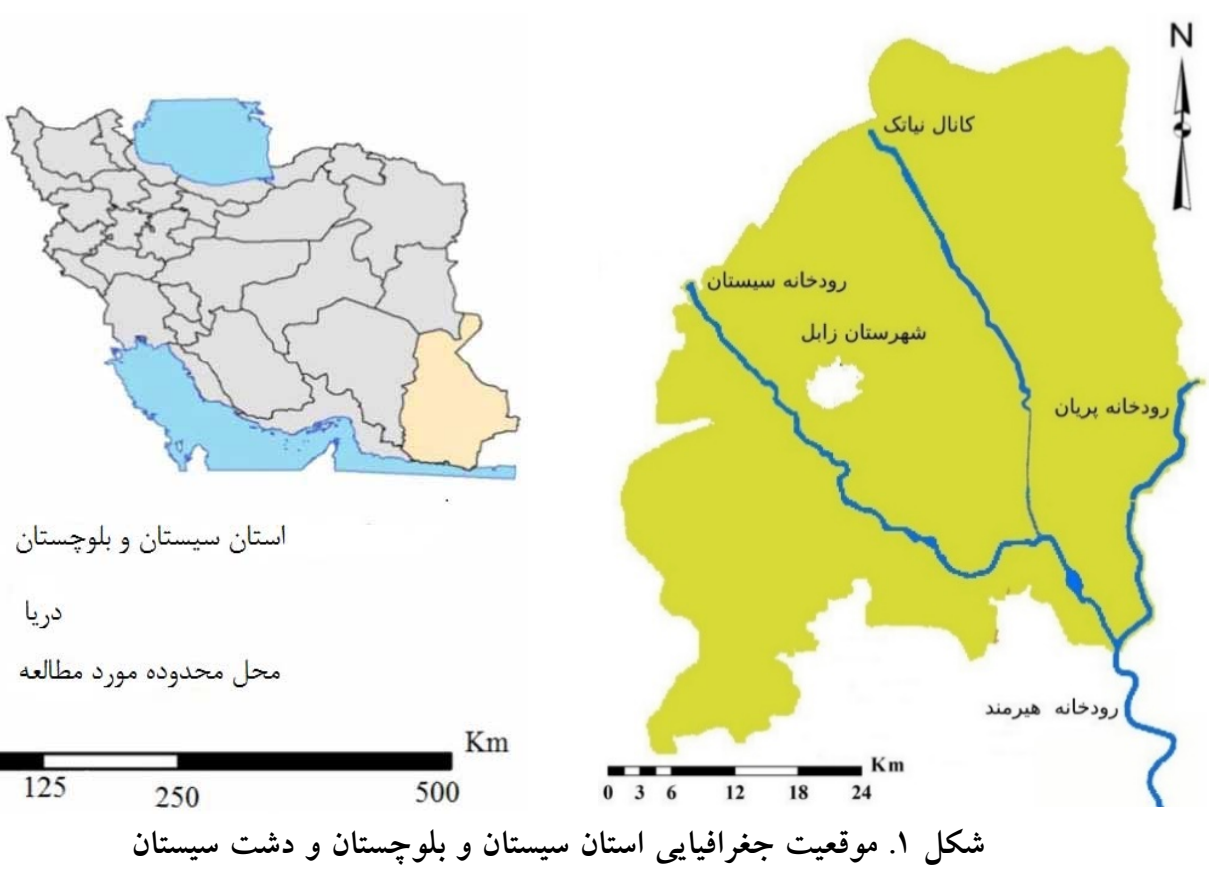

جدول ا. ميانخين آمارى يارامترهاى استفاده شده در مدلسازى تبخير - تعرق بتانسيل روزانه (ايستخاه سينويتيك زابل)

\begin{tabular}{|c|c|c|c|c|c|c|}
\hline سطح دريا (متر) & ساعات آفتابى & (ميلى متر ) & (متر بر ثانيه) & رطوبت نسبى & $\begin{array}{c}\text { (درجه سانتى گراد) } \\
\text { (دماد) }\end{array}$ & 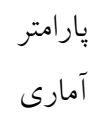 \\
\hline \multirow{5}{*}{ 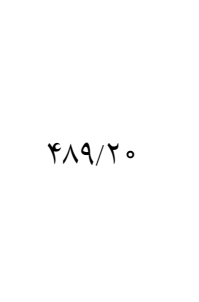 } & $9 / 11$ & $\circ / \circ \mu$ & $|r / \mu|$ & $r q / \wedge D$ & D & ميانخين \\
\hline & $9 / V_{0}$ & $\circ$ & ir & $r V / D \circ$ & $r \mu / \Lambda 。$ & ميانه \\
\hline & V/AY & ०/०M & rN/qT & $T Y \Lambda / \Delta D$ & $10 Y / Y Q$ & واريانس \\
\hline & $-1 / \Delta Y$ & $\mathrm{~V} / \mathrm{IT}^{\mathrm{C}}$ &.$/ 19$ & $0 / 94$ & $-r / T Y$ & جִ لكىى \\
\hline & $T / T \Lambda$ & $\Delta r / \Lambda$ & $-0 / 91$ & $-0 / \mathcal{E}$ & $-I / T Y$ & كشيد كى \\
\hline
\end{tabular}

سينويتيك زابل جمعآورى شده است. در اين ايستخاه، آمار

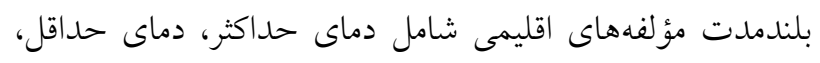

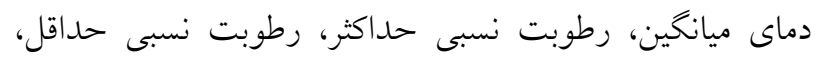

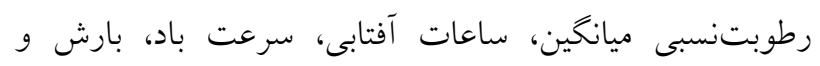

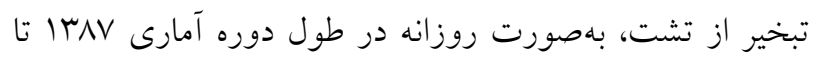

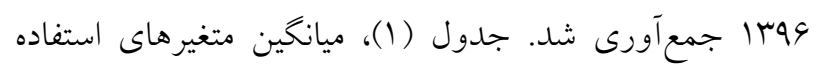
شده براى مدلسازى تبخير - تعرق پِّانسيل روزانه در طول دوره آمارى براى دشت سيستان را نشان مى دهد. دادهاى خام هواشناسى روزانه بين سالهاى مذكور

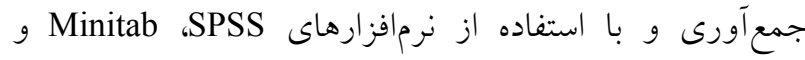

ه r دقيقه عرض شمالى و ا9 درجه و ه ا دقيقه تا ا9 درجسه

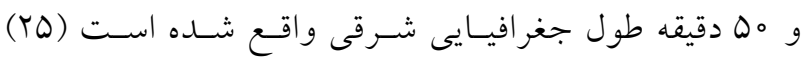

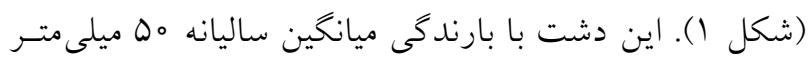

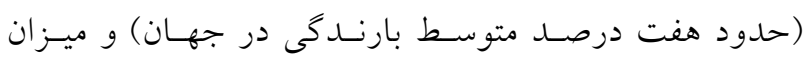

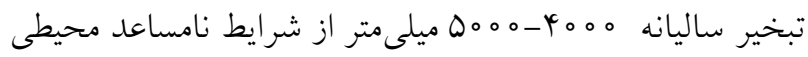

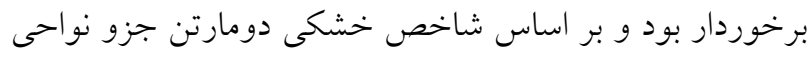
فر اخشك محسوب مى شود. از علائم مشخصه دشـت سيستـان

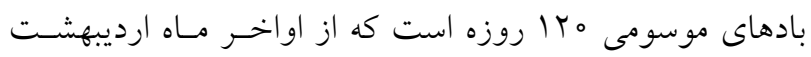
بلهورت بيوسته و گاهى گسسته مى موزد. دادهاى استفاده شده در اين يزوهش از ايستكاه هواشناسى 


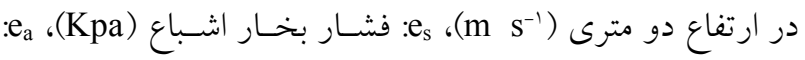
فشار بخار واقعى (Kpa) است.

\section{متغيرهاى ورودى به مدلها} در اين تحقيق با توجه بــه دادههـاى وروددى روزانـه كـه شـامل شاخص روزانه دماى حداكثر، دمـاى حـداقل، دمـاى ميـانكين، رطوبت حــاكثر، رطوبـت حـــاقل، رطوبـت ميـانكين، بـارش، ساعات آفتابى، سرعت باد و تبخير از تشـت هسـتند، الخوهــاى مختلفى (ها الكو) كه بتوانــ تركيبـات مختلـف از يار امترهـاى هواشناسى را دربر گيرد، ارائه شد (جدول Y).

\section{مدل خطى تعميميافته (GLM)}

مدلهاى خطى تعميميافته، بهطور كلى ابزارهايى تحليلى بـراى انواع دادههاى مختلف هستند و روابط رياضى آن توسط نلدر و باكر (YT)، تهيه شد. تئورى اين مدل توسط مـى كـالاگ (Y) (Y)، توسعه داده شد و بهوسيله جندلر و وياتر (†) براى موضـوعات

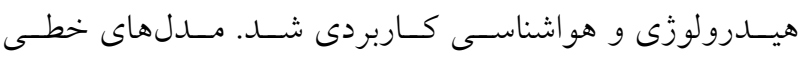
تعميميافته شامل طيـف كسـتردهاى از مـــلهــاى آمـارى نظيــر ركرسـيون خطى بـراى ياسـخ توزيـع شـــه نرمـال، مـدلهاى لجستيك براى دادهاى باينرى، مدلهاى خطى بــراى دادههـاى شمارشى و همجنِين بسيارى از مدلهاى آمارى مفيـد از طريـق

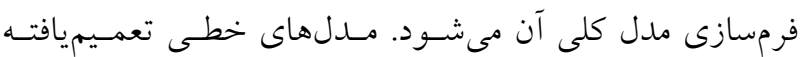

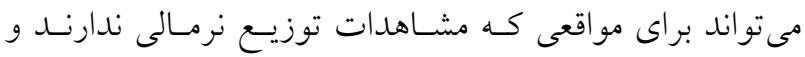
زمانى كه ساير روشهاى مدل ركرسيون مناسب نيسـتند، بـهـار رود. عملكرد اين مدل، در بين روشهـاى معمـول مدلسـازى، قابل قبول است (צY). بسيارى از يزٔوهشـخران از ايسن روش در

مدلسازى و يِيشبينى هاى بارش استفاده كردهاند (Y و سY).

مدل جنگل تصادفى (RF)

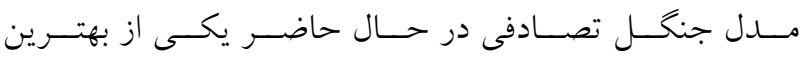
الكوريتمهاى يادكيرى است و براى بسيارى از مجموعه دادههـا، دستهبندى را با سرعت بالايى انجام مىدهد. اين روش كه بيشتر
ييش يردازشهاى لازم بهمنظور حذف MATLAB (R2017b)

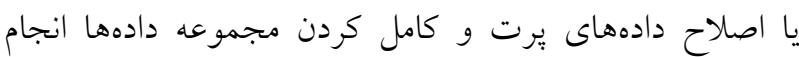
شد. در اين تحقيق، روش مبنا براى محاسبه مقدار تبخير - تعرق

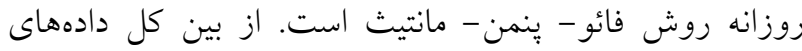

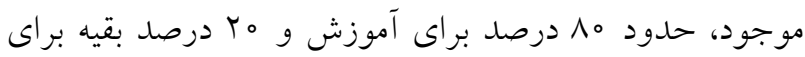

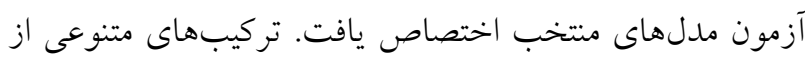
دادههاى هواشناسى بلعنوان ورودى مدلها و مقادير محاسبه شده

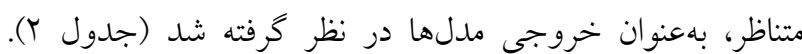
نتايج حاصل از الكوهاى تركيبات مختلف، بررسى شده و بهترين سناريوى انتخابى، براى بيشبينى مقادير تبخير- تعرق،

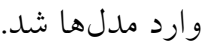

معادله ينمن- مانتيث

روش فائو - يُنمن - مانتيث، تكامل يافته روش تركيبى ينمن - مانتيث 1990 است كه توسط آلن و همكاران (1) براى محاسبه

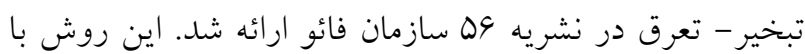
دقت بالا در محدوده وسيعى از مناطق و اقليمها برآورد

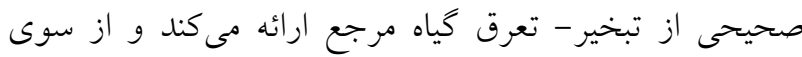

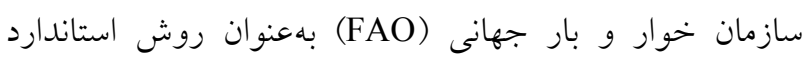

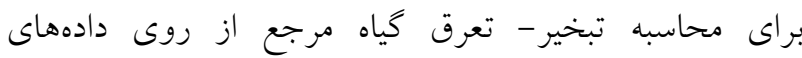
هواشناسى و اقليمى و همجنين براى ارزيابى ساير روشها

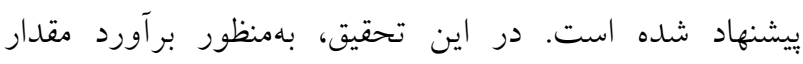

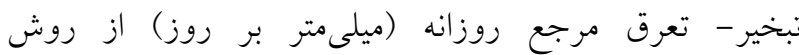
فائو - يُمن - مانتيث مطابق معادله زير استفاده شد (1): $\mathrm{E}_{\mathrm{PM} \Delta \varphi}=\frac{0, \varphi_{0} \wedge \Delta\left(\mathrm{R}_{\mathrm{n}}-\mathrm{G}\right)}{\Delta+\gamma\left(1+0, \mu u_{r}\right)}+$

$$
\frac{q \circ \circ \gamma}{\left[\Delta+\gamma\left(1+\circ, \mu^{\prime} u\right)\right]} \frac{u_{r}\left(e_{s}-e_{a}\right)}{(T+r V r)}
$$

در رابطه فوق ET : تبخير - تعرق كيـاه مرجـع (mm day 4: شيب فشار منحنى فشار بخار اشـباع (Kpa C

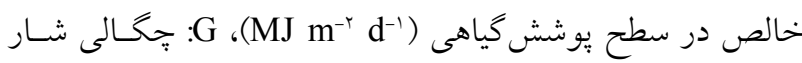

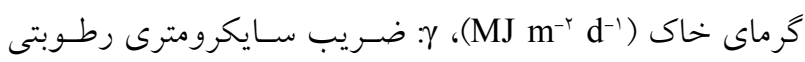
Thean (Kpa C C 
جدول r. الكوهاى به كار بردهشه در مدلهاى بيشنهادى براى برآورد تبخير-تعرق يتانسيل

\begin{tabular}{|c|c|c|}
\hline تعداد متغيرها & بارامترهاى ورودىى شبكه & الكو \\
\hline 10 & آفتابى، سرعت حداكث، دماى حداد، تبخير از تشت، دماى ميانخين، رطوبت حداكثر، رطوبت حداقل، رطوبت ميانخين، بارش، سـاعات & M1 \\
\hline 9 & داد، تبخير از تشاقل، دماى ميانخين، رطوبت حداكثر، رطوبت حداقل، رطوبت ميانخين، بارش، ساعات آفتابى، سرعت & M2 \\
\hline 9 & 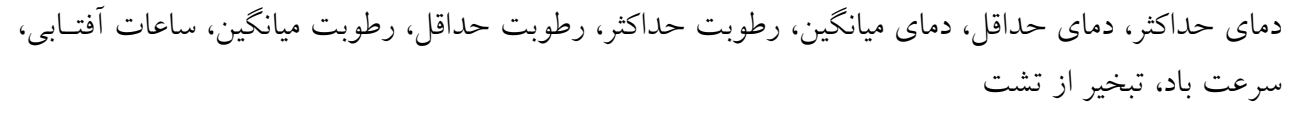 & M3 \\
\hline$\wedge$ & تبخير از تشت حداكث، دماى حداقل، دماى ميانكين، رطوبت حداكثر، رطوبت حداقل، رطوبت ميانخين، ساعات آفتـابى، & M4 \\
\hline$\wedge$ & تبخي از تشت حمثر، دماى حداقل، دماى ميانگين، رطوبت حداكثر، رطوبت حداقل، رطوبـت ميـانخين، سـرعت بـاد، & M5 \\
\hline$v$ & دماى حداكثر، دماى حداقل، دماى ميانكين، رطوبت حداقل، رطوبت ميانخين، سرعت باد، تبخير از تشت & M6 \\
\hline 9 & دماى حداكثر، دماى حداقل، دماى ميانخين، رطوبت ميانگين، سرعت باد، تبخير از تشت & M7 \\
\hline 0 & دماى حداكثر، دماى ميانكين، رطوبت ميانكين، سرعت باد، تبخير از تشت & M8 \\
\hline$r$ & دماى ميانكين، رطوبت ميانكين، سرعت باد، تبخير از تشت & M9 \\
\hline$r$ & دماى حداكثر، رطوبت ميانخين، سرعت باد، تبخير از تشت & M10 \\
\hline r & دماى حداكثر، رطوبت ميانخين، تبخير از تشت & M11 \\
\hline r & دماى حداكثر، سرعت باد، تبخير از تشت & M12 \\
\hline r & دماى حداكثر، سرعت باد & M13 \\
\hline 1 & دماى حداكثر & M14 \\
\hline 1 & سرعت باد & M15 \\
\hline 1 & تبخير از تشت & M16 \\
\hline r & دماى حداكثر، دماى حداقل & M17 \\
\hline 1 & رطوبت ميانكين & M18 \\
\hline r & 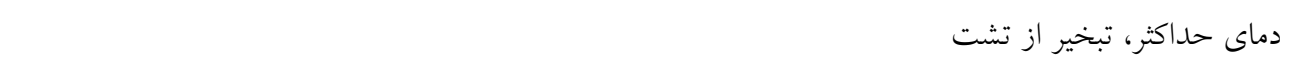 & M19 \\
\hline r & دماى حداكثر، رطوبت ميانكين & M20 \\
\hline r & دماى حداكثر، رطوبت حداكثر & M21 \\
\hline r & دماى ميانخين، سرعت باد & M22 \\
\hline r & دماى حداكثر، سرعت باد & M23 \\
\hline 1 & ساعات آفتابى & M24 \\
\hline 1 & دماى حداقل & M25 \\
\hline
\end{tabular}




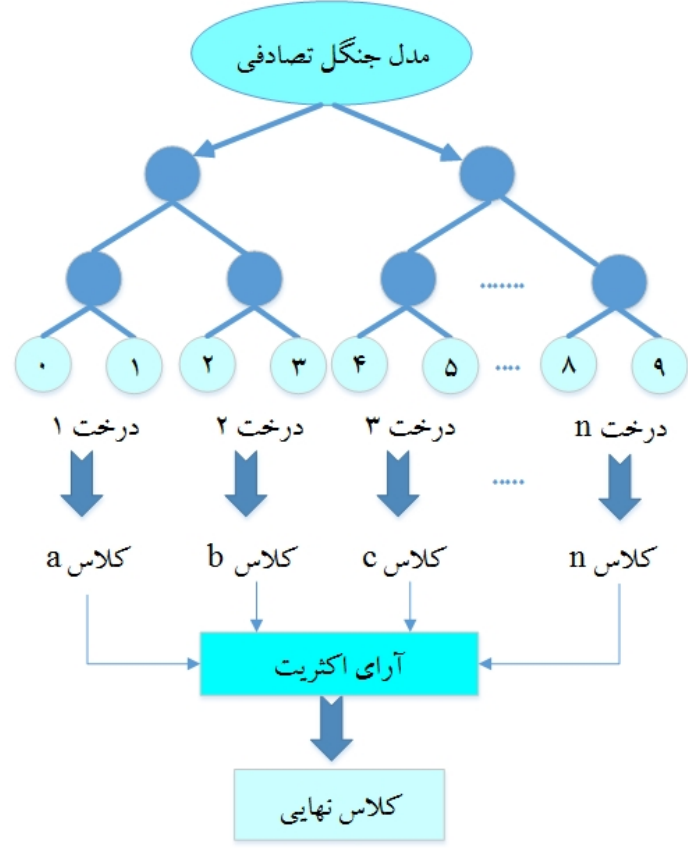

شكل r. ساختار و اجزاى مدل جنگل تصادفى (rq)

كه براى ارائه بيشبينىهاى خروجى نسبت به ديخر الكوريتمهـا

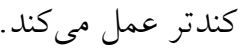

در اين يزوهش، بـهمنظـور انتخـاب مناسـبتـرين خـط برازشيافته توسط اين روش در احتمالات متفاوت، متغير اندازه كره (Node size) كه نشاندهنده تعداد بركَهـا در هـر شـاخه است، با آزمون و خطا تعيين شد.

مدل درخت گراديان بوستينى (GBT) روش درخـت كراديـان بوسـينگ جـزء بهتـرين الكوريتمهـاى يادگيرى است و براى بسيارى از مجموعه دادهها، دستـنبندى را با دقت بالايى انجام مىدهد. در اين روش، درختها يكى ؛سس

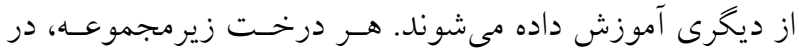
درجه اول بـا دادهـايى كـه بـه اشـتباه توسط درخـت بيشـين يميشبينى شدهاند، آموزش داده مىشوند (1)). اين امـر موجـب

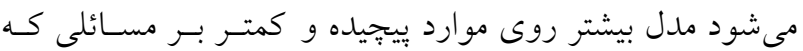

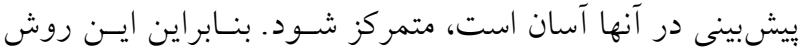
نسبت به بسـيارى از روشهـا مانــــ روش رگرسـيون خطى و

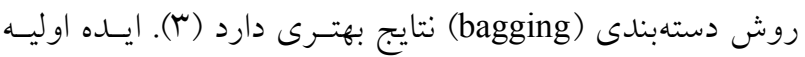

براى يِشبينى تشعشع خورشيدى ساعتى شـناخته شـده اسـت

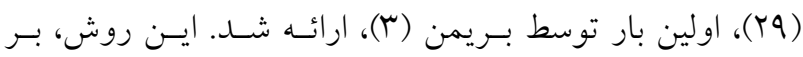

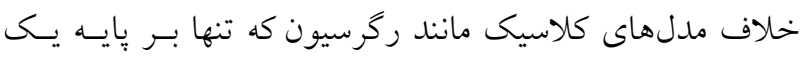
مدل تكيه دارند با استفاده از تعداد زيـادى درخـت تصـميم، از اطلاعات بيشترى در دادهها استفاده مى كند. سيس تمام درختـان

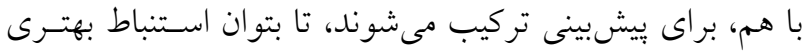

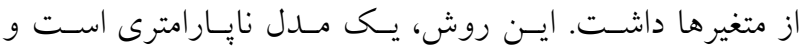

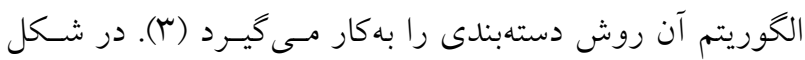
(Y)، ساختار و اجزاى اين مدل نشان داده شده است. جنكال تصادفى با اسـتفاده از مجموعسهاى از درخـتهــا بـا درنظر گرفتن n داده مشاهدهاى مستقل ساخته مى $\left(Y_{i}, X_{i}\right), i=1,2, \ldots, n$

اين روش تركيبى از جندين درخت تصميم است كه در ساخت

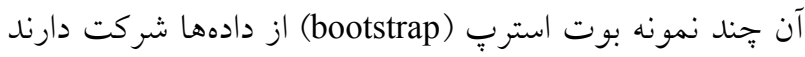
و در ساخت هر درخت بهطور تصـادفى تعـدادى از متغيرهـاى

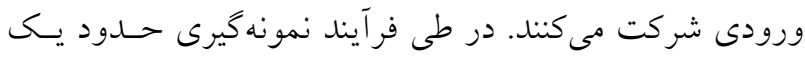
سوم از دادهها نمونه كيرى نمىشوند و بهعنوان نمونسه خـارج از كيسه درنظـر كرفتـه مسىشـوند و از ايسن دادههـا بــــاى تعيسين

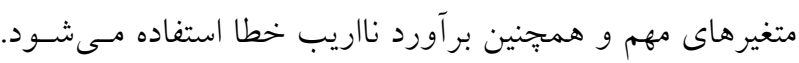
سبس روى هر نمونه بوتاسترٍ، يـك درخـت گسـترش داده مىشود. در طى فرايند ساخت درخت در هر شاخه، از بين تمام Mتغير مستقل بهصورت تصادفى، m متغير براى تقسيم شـدن فرن

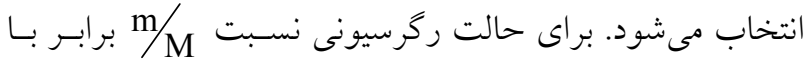

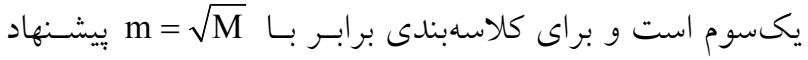

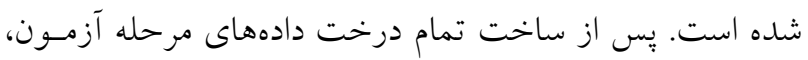
به درخت معرفى شده و به تعداد درختها براى بـردار ورودى لمع

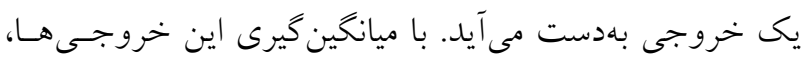

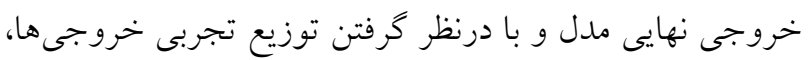

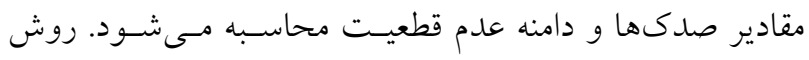

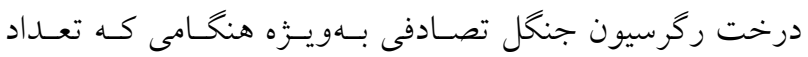

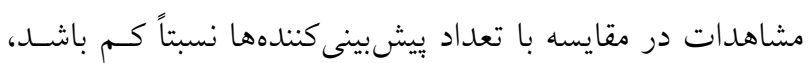

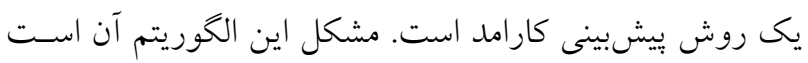


RMSE $=\sqrt{\frac{\sum_{\mathrm{i}=1}^{\mathrm{N}}\left(\mathrm{O}_{\mathrm{i}}-\mathrm{P}_{\mathrm{i}}\right)^{r}}{\mathrm{n}}}$

در اين روابط، OOi مقادير واقعى،

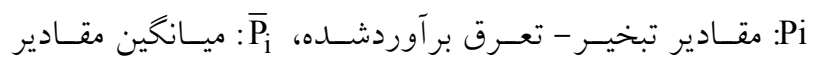
برآوردشده، N: تعداد دادهها است.

\section{تحليل حساسيت}

هدف از تحليل حساسيت در ايسن پـرزوهش شناسـايى و تعيسين درجه اهميت هر يك از بارامترها در سرى دادههاى ورودى بـر عملكرد ديناميكى سيستم است. بلمنظور آناليز حساسيت در هر

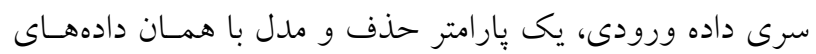

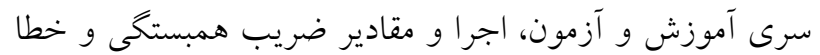

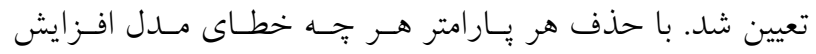

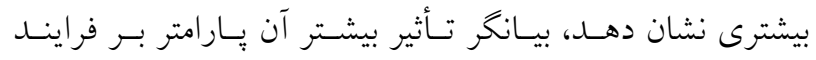
شبيهسازى است.

براى انتخاب مناسبترين مدل بر اساس معيارهـاى خطـاى است

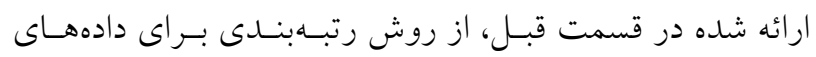

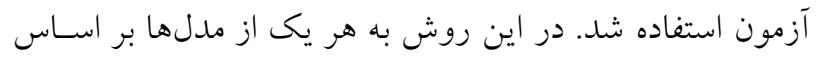

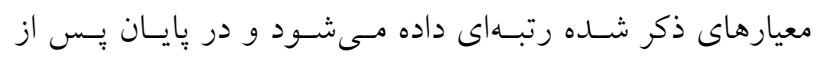

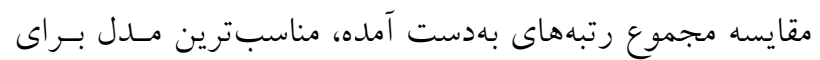

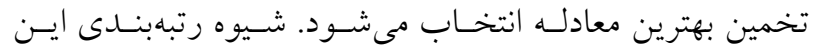
مدلها بدين صورت است كه در هر روش، مـدلى كـه كمتـرين ميزان خطاى RMSE را دارد، يـايينتسرين رتبـه (رتبـه ()) و بــهـ

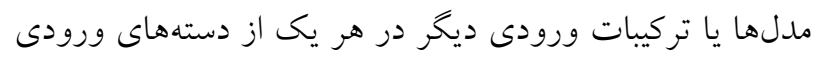

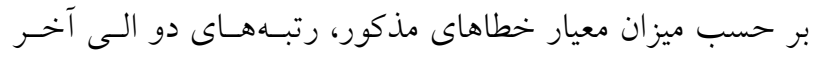

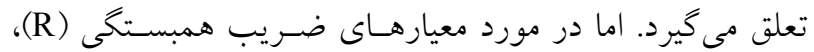
مدل يا تركيبى كه بيشترين مقدار اين معيارها را دارا است، رتبـهـ يك اختصاص مى يابد. همجتينين به مــلهـايى كـه ميـزان معيـار

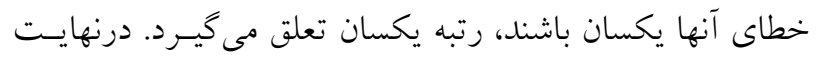

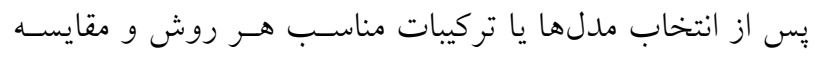

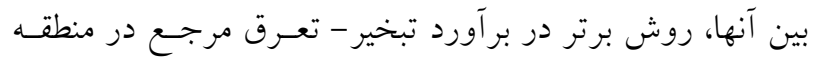
مورد مطالعه انتخاب مىشود.
اين روش توسط بريمن (Y) ايسن روش را بـهـعنوان روشى كـه

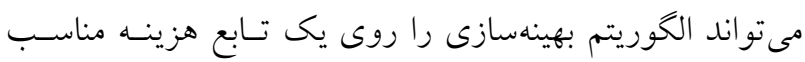

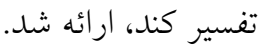

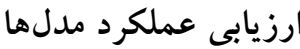
بررسى نحوه عملكرد و مقايسه قدرت ييشينى بهمنظور مقايسه عملكرد مدلها لازم و ضرورى است. در اين مطالعه، علاوه بـر ترسيم نمودارهاى مقادير واقعى در برابـر مقــادير بيشبينىشــــ

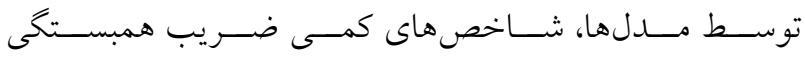
Correlation coefficient ،R) و خطــاى جـــر ميـانخين (Mean Absolute Error ،MAE) مربعـات (Root Meas Square Error ،RMSE) بـهـعنـوان معيارهاى ارزيابى به كار گرفته شد (روابط r تا ه). الف) ضريب همبستخى: بيانكننده همبستخى بين مقادير بـر آورد شده مدل و دادههاى واقعى (روش فائو - ينمن - مانتيث) اسـت فئس (رابطهr). بر اين اساس هر جهه مقدار آن به يكى نزديكتر باشــد،

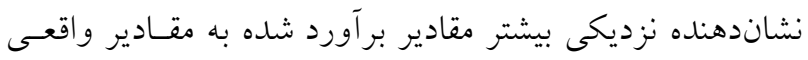

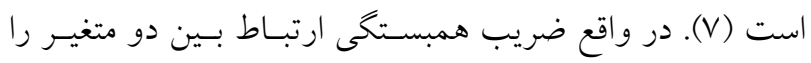

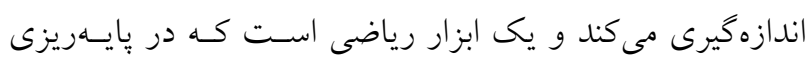

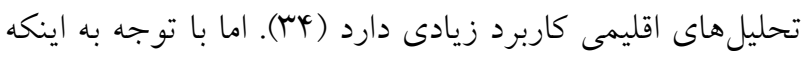
اين ضريب به دادههاى خارج از محدوده حساسيت زيادى دارد، از

اينرو نمى تواند بهتنهايى براى ارزيابى يكى مدل بهكار رود (V).

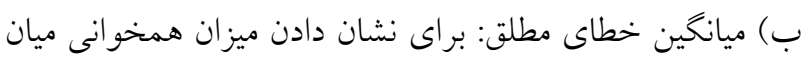

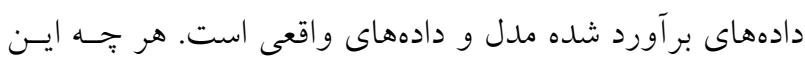
شاخص كه بــدون علامـت اسـت، بـهـ صـفر نزديـكتر باشـد، نشاندهنده انحر اف كمتر و دقت بالاتر مدل است (ه (1). ج) خطاى جذر ميانكين مربعات: اين بارامتر نشـاندهنده ميـزان خطاى مدل است كه بهترين مقدار آن صفر است.

$$
\mathrm{R}=\frac{\sum_{\mathrm{i}=1}^{\mathrm{N}}\left(\mathrm{O}_{\mathrm{i}}-\overline{\mathrm{O}}_{\mathrm{i}}\right)\left(\mathrm{P}_{\mathrm{i}}-\overline{\mathrm{P}}_{\mathrm{i}}\right)}{\sqrt{\sum_{\mathrm{i}=1}^{\mathrm{N}}\left(\mathrm{O}_{\mathrm{i}}-\overline{\mathrm{O}}_{\mathrm{i}}\right)^{r} \sum_{\mathrm{i}=1}^{\mathrm{N}}\left(\mathrm{P}_{\mathrm{i}}-\overline{\mathrm{P}}_{\mathrm{i}}\right)^{r}}}
$$

$\operatorname{MAE}=\frac{\sum_{\mathrm{i}=1}^{\mathrm{N}}\left(\left|\mathrm{O}_{\mathrm{i}}-\mathrm{P}_{\mathrm{i}}\right|\right)}{\mathrm{N}}$ 


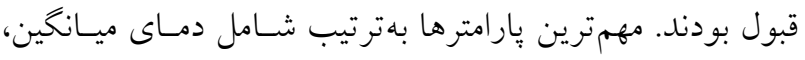

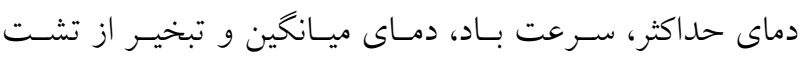

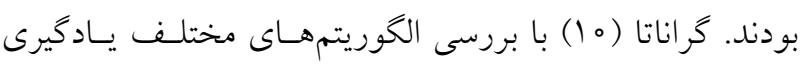

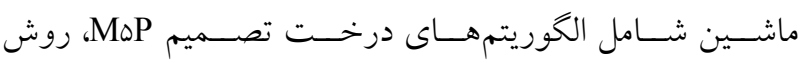
دستهبندى (bagging)، روش جنغل تصادفى و روش رگرسيون بـردار يشـتيبانى (Support Vector Regresssion SVR) و همجنين الكوهاى مختلف متغيرهاى هو اشناسى و مقايسه آنها با روش فائو - پنمن - مانتيث در منطقهاى با اقليم مرطوب، استفاده

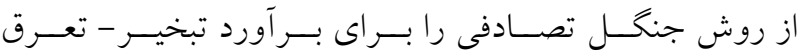

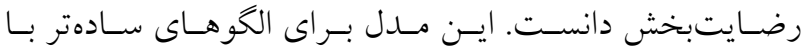

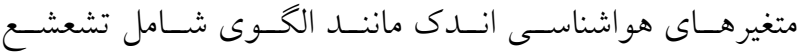
خورشيدى خالص، سرعت باد، دماى ميانخين و رطوبت نسـبى هوني

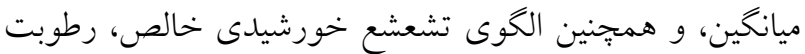
نسبى ميانخين و دماى ميانخين نتايج بهتر از ساير روشهين ها ارائسه

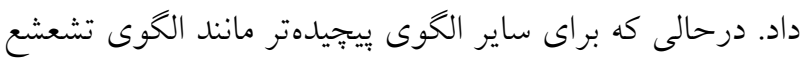

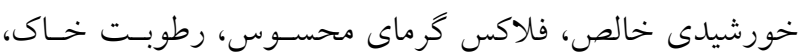

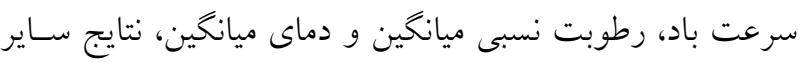

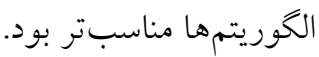

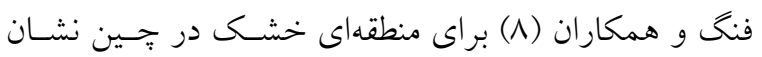

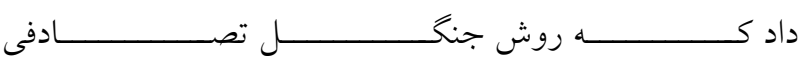

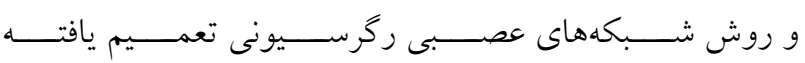
(Generalized Regression Neural Networks ،GRNN) مناسبى در تخمين تبخيـر - تعـرق روزانسه داشـتند و نتـايج روش

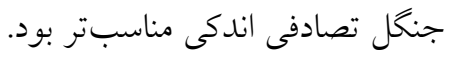

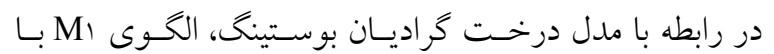

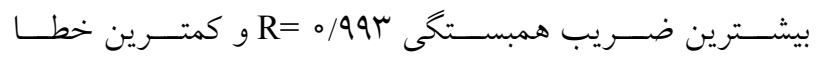

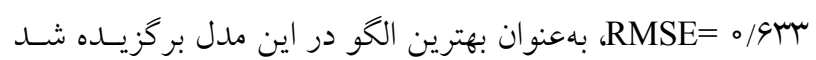

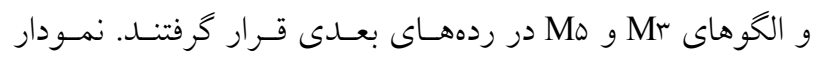

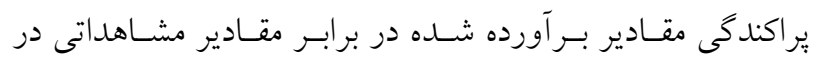

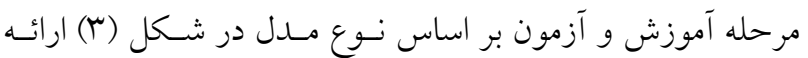
شلده است.

نتايج همبسـتكى بـالاى بـين تبخيـر - تعـرق بـر آوردشــده از

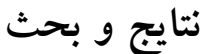
با محاسبه مقادير تبخير - تعرق مرجع با روش فائو - ينمن - مانتيث

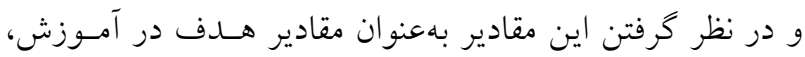

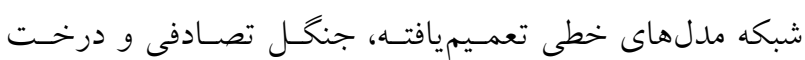

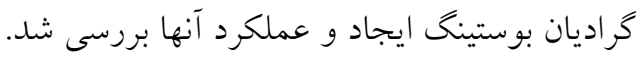

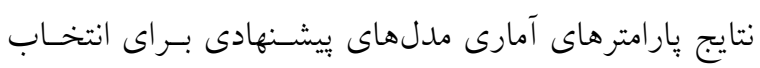

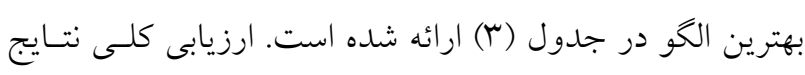

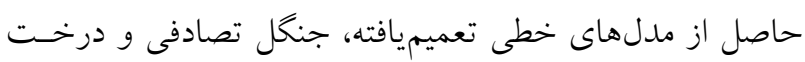

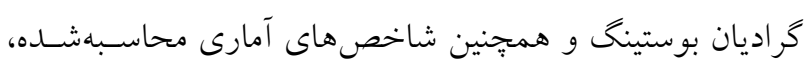

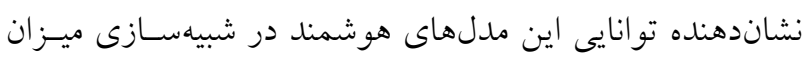
تبخير - تعرق روزانه منطقه مورد مطالعه است.

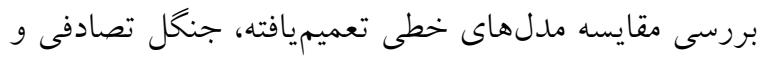

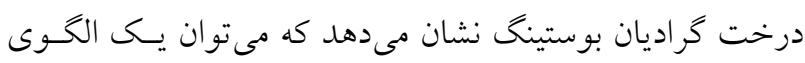

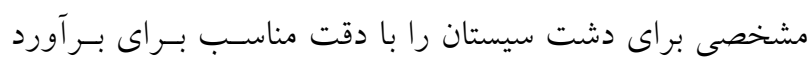

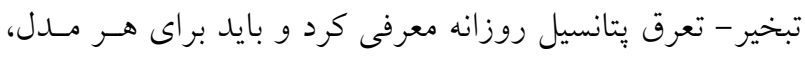

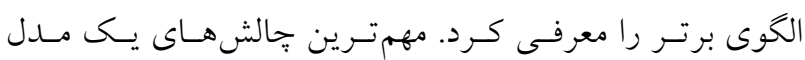

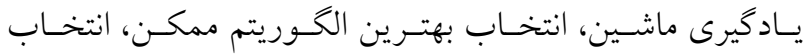

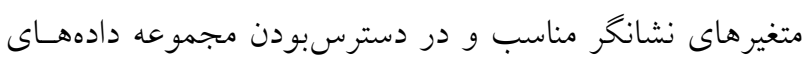

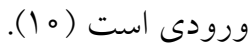

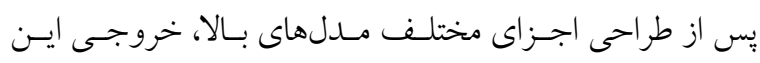

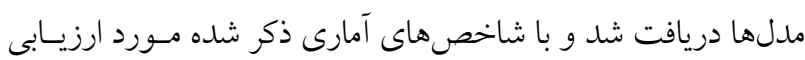

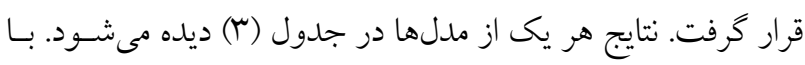

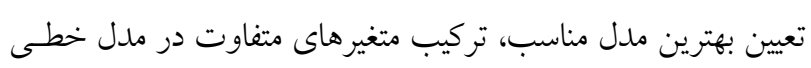

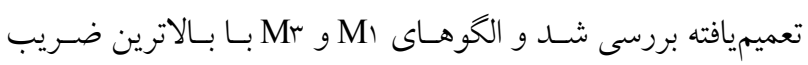

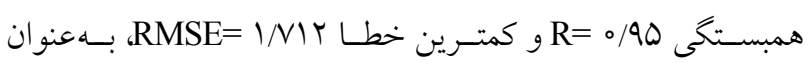
بهترين الكوها انتخاب شدند (جدول بمان.

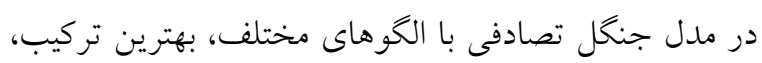

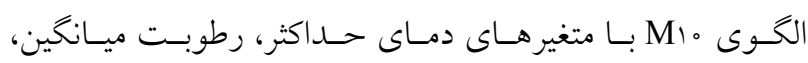

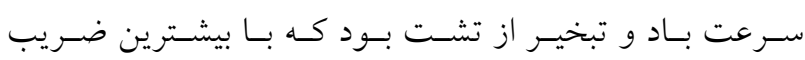

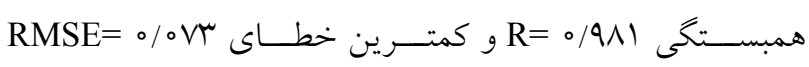

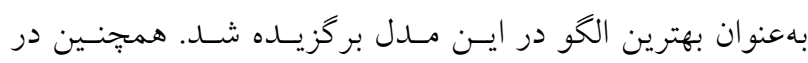

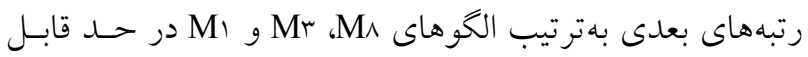


جدول r. ضريب همبستگى و خطاى الكوهاى مختلف در مدلهاى بيشنهادى در ايستخاه مورد مطالعه

\begin{tabular}{|c|c|c|c|c|c|c|c|c|c|}
\hline \multicolumn{10}{|c|}{ مدل بيشنهادى } \\
\hline \multicolumn{3}{|c|}{ درخت گراديان بوستينگ } & \multicolumn{3}{|c|}{ جنگل تصادفى } & \multicolumn{4}{|c|}{ مدل خطى تعميميافته } \\
\hline \multicolumn{10}{|c|}{ شاخص هاى آمارى } \\
\hline ميانخين مربعات جذر & خطاى & ضريب & ميانخين مربعات جذر & خطاى & ضريب & ميانخين مربعات جذر & خطاى & ضريب & الخو \\
\hline سM/g. & $0 / Y Q D 1$ & $0 / 994$ & $I / \backslash \wedge V$ & $0 / 94 q$ & $0 / 9 V 1$ & I/VIY & I/MKY &.$/ 900$ & $\mathrm{M}_{1}$ \\
\hline -/VQY &.$/ 490$ & $0 / 990$ & $1 / r q r$ & ./9Tr & $0 / 9 V T$ & $|/ V Q|$ & $1 / \pi 40$ &.$/ 94 \Delta$ & Mr \\
\hline سחو/. & $0 / Y Q D 1$ &.$/ 994$ & $I / \backslash \wedge V$ & $0 / A r q$ &.$/ 9 \mathrm{VV}$ & I/VIT & I/MKT & $\circ / 900$ & $\mathrm{Mr}$ \\
\hline$r / \circ \circ \Delta$ & $1 / \mu \psi_{0}$ & . & $T / \circ V Q$ & $1 / \mu q r$ &.$/ 9 T V$ & T/TVY & l/gkt & $0 / 91 Y$ & Mr \\
\hline $0 / G M V$ & O/KGY &.$/ 994$ & $1 / 190$ & - NATD & $0 / 9 V 9$ & $1 / \mathrm{V} 10$ & $1 / T Y Q$ &.$/ 900$ & $\mathrm{M}_{\Delta}$ \\
\hline $0 / 991$ & $0 / 49 \Lambda$ & $0 / 994$ & $1 / T \Delta Q$ & - MMY & $0 / 9 V^{4}$ & l/var & $1 / 4 \circ Y$ &.$/ 940$ & Ms \\
\hline $0 / 990$ & o/ & $0 / 9 V 4$ & $1 /$ TYq & -/AVY & $0 / 9 V 4$ & l/Vq4 & $1 / 401$ &.$/ 940$ & $\mathrm{M} \vee$ \\
\hline $0 / 9 \vee 9$ & $0 / 4 q 0$ & $0 / 994$ & I/ONY & $\circ / \Lambda \circ \circ$ &.$/ 911$ & $1 / 1 / 0$ & $|/ 4| 4$ & $0 / 9 k 4$ & $\mathrm{M} \wedge$ \\
\hline 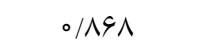 & - 094 & $0 / 9 \wedge \mathrm{V}$ & I/IKY & O/ATV & $0 / 9 \vee q$ & $1 / 9 \mathrm{VV}$ & $1 / 0 \circ \Lambda$ & ./9M & Ma \\
\hline olgra & o/sVy & $0 / 994$ & $1 / 0 V \pi$ & $\circ / \Lambda \circ \circ$ & $0 / 911$ & $1 / \Lambda \circ r$ & $1 / 4 \circ \Delta$ &.$/ 940$ & M1。 \\
\hline$r / T r q$ & $1 / \Delta \Delta \wedge$ & $0 / 914$ & T/TGV & $1 / 094$ & $0 / 91 Y$ & T/FYG & $1 / \wedge 11$ & $0 / 194$ & M।I \\
\hline $1 / \pi \circ \psi^{r}$ & $0 / 991$ & $0 / 971$ & $1 / 44 q$ & $1 / 109$ & $0 / 990$ & $1 / 9 \wedge \mathrm{V}$ & $1 / 0 \wedge 9$ & سM/9M & MIr \\
\hline $1 / \Upsilon \wedge 。$ & $1 / 090$ & $0 / 99 \mathrm{~V}$ & l/kys & سו1/1 & $0 / 944$ & T/YIY & I/AMI &.$/ 91 \mathrm{~V}$ & Mir \\
\hline$r / 4 q 1$ & T/909 & ०/AYV & T/QTY & $r / 999$ & -NAM & נָ & $r / 994$ & -NGY & Mie \\
\hline $0 / 4 \mid \Lambda$ & $\varphi / r \wedge q$ & $0 / 001$ & $\Delta / 4 \circ \Lambda$ & $\varphi / r \wedge \Delta$ & $\circ / 0 \circ r$ & $0 / 4 \mid \lambda$ & $r / \mu \circ r$ & $0 / 0.1$ & M10 \\
\hline$r / \circ q \psi$ & T/YqT & ०/AMV & r/T & T/MTY & אח//. & $r / \tau \circ \circ$ & $r / 4 \mid Y$ & -/ATO & Mis \\
\hline r/949 & $1 / 94 Y$ & $\circ / M N \mid$ & $r / 9 \mathrm{VI}$ & $1 / 94 \wedge$ & ०/AVq & r/入 & T/QTY & -/ATO & $M \backslash V$ \\
\hline$r / q Y_{0}$ & $r / q V \mu$ & $\circ / N \mu_{q}$ & $r / Q T V$ & $r / 94 \Lambda$ & $\circ / N r V$ & $0 / \circ 9 \circ$ & $r / q 40$ & $\circ / 0 \Delta Q$ & $M \backslash \wedge$ \\
\hline$r / \varphi \wedge r$ & $1 / \mathrm{VVV}$ & $0 / 190$ & $r / \Delta \circ \Delta$ & l/AY。 & -/NqR & $r / D V I$ & $1 / 91 Y$ & - $/ A M$ & $M 19$ \\
\hline T/VKT & 1/99r & O/AVY & $r / N{ }^{\mu}$ & $1 / 909$ & -/AVT & r/rvg & $\mathrm{r} / 9 \mathrm{VV}$ & $0 / 109$ & Mr。 \\
\hline$r / 910$ & $1 / 199$ & -/MAY & $r / 9 \circ r$ & $1 / \wedge \Delta Y$ & - $/ \Lambda \Lambda F$ & $r / \circ V \psi^{e}$ & $r / 4 \mid \Lambda$ & - /Arq & Mrl \\
\hline $1 / 909$ & ואוץו & $0 / 909$ & l/GKV & $\mid / T V I$ & - $/ 90 Y$ & $r / \mathcal{C} \circ \circ$ & $1 / 909$ & $\circ / 9 \circ Y$ & Mrr \\
\hline $1 / \Gamma \wedge 。$ & $1 / 090$ & $0 / 99 \mathrm{~V}$ & 1/4ke & س &.$/ 944$ & $T / T I T$ & | ו ו &.$/ 91 \mathrm{~V}$ & Mrr \\
\hline D/GTY & $\varphi / \varphi \Delta \circ$ & $0 / 490$ & D/GKY & $\varphi / \varphi \Delta r$ & - $A \Delta Q$ & $9 / 490$ & $D / D G Y$ & $0 / T \wedge q$ & Mre \\
\hline$r / 9 \Lambda 1$ & $\Gamma / \circ \wedge \varphi$ & -/AG० & $r / 901$ & $r / \| r$ & -/ADG & T/TKT & $r / 91 T$ & o/NIT & Mro \\
\hline
\end{tabular}

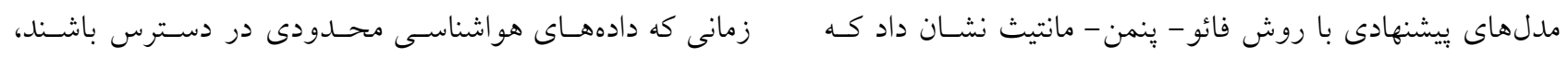

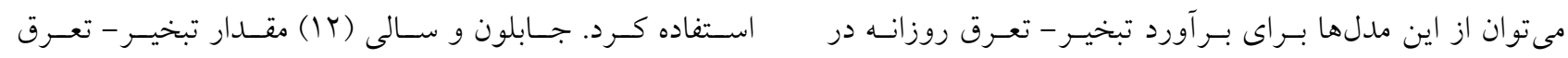



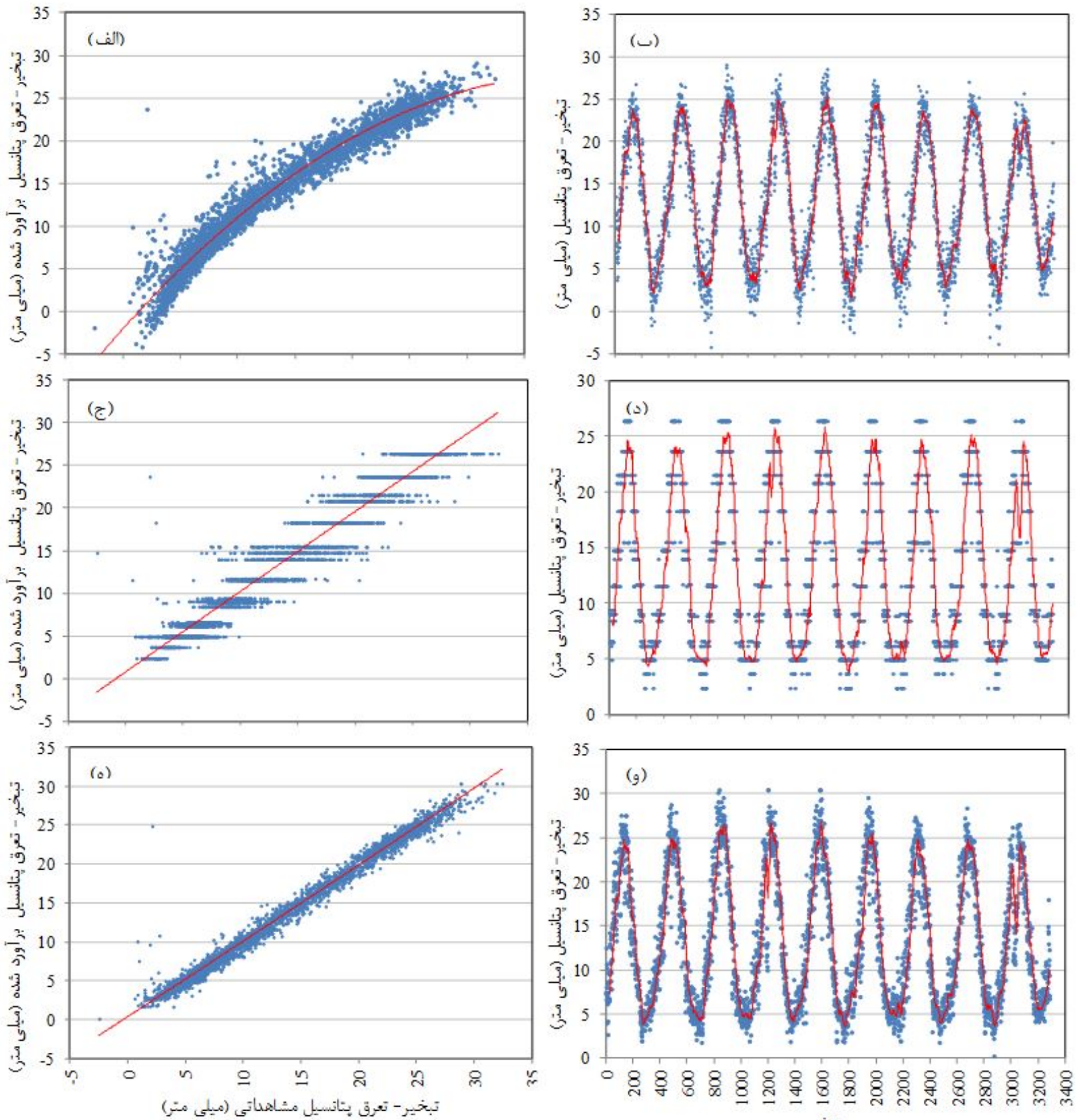

شكل r. همبستخى و بر اكنش بين مدل فائو - ينمن - مانتيث با (الف و ب) مدل درخت گر اديان بوستينى (GBT)، (ج و د) مدل خطى تعميميافته (GLM) و (هو و) مدل جنكل تصادفى (RF) (الخوى يك)

استفاده از دادهاى روزهاى قبـل (previous days strategy) و نيز روش كلاسترينخ (clustering) بهره كيرى كرد. نكته ديخر در بحث مدلسازى بـا مــلـهاى مـــكور، زمـان مورد نياز براى محاسبات شبيهسازى است. با توجه به اينكـه در

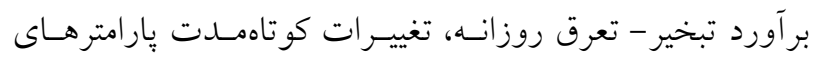

محاسـباتى را بــا اسـتفاده از دو مجموعـهـ محســود و كامـل از دادههاى هواشناسى در تونس مقايسه كردند و تفاوت بين نتايج

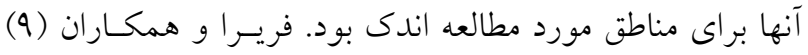

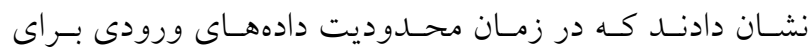

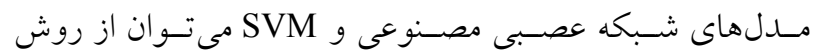




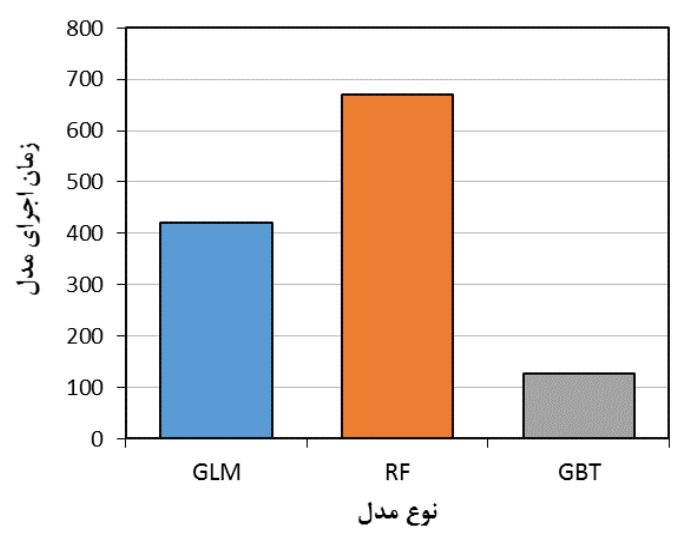

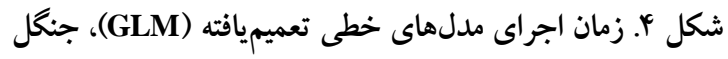

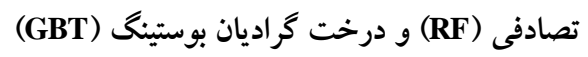

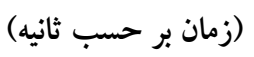

بر اساس نتايج، در مجموع يارامتر دما بهعنوان مهمترين :ـارامتر

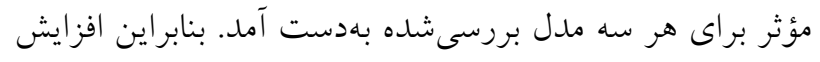

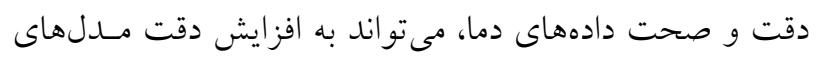

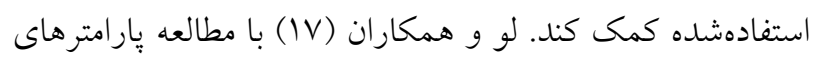
مختلف هواشناسى در تخمين تبخيـر - تعـرق توسط مـــلهاى

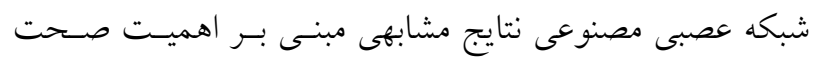

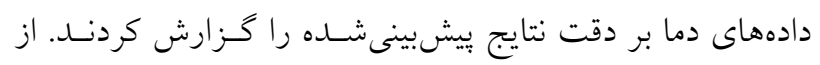

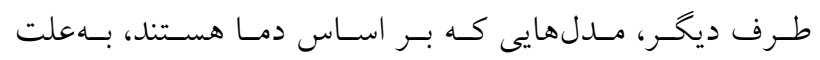

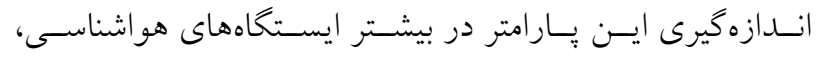

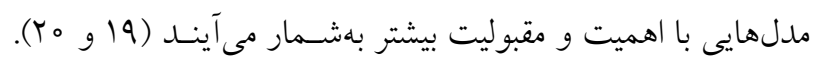

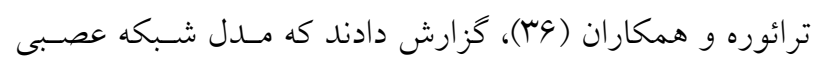

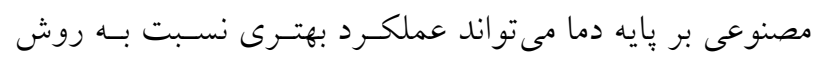

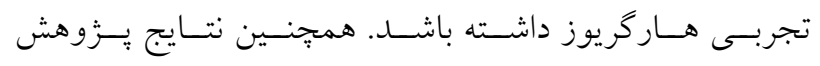

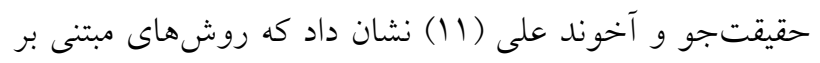
دماى هوا، تبخير - تعرق دشت سيستان را بهتر بر آورد مى كند. بنابراين در مدل درخت كراديـان بوسـتينگ، بهتـرين الحَّو،

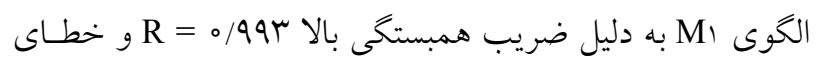

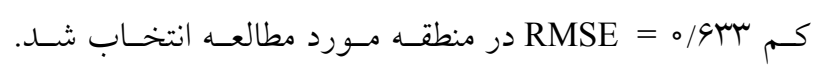

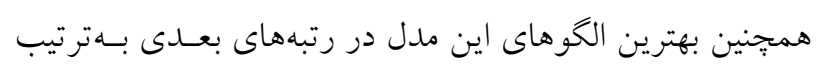
M و $\mathrm{M} ه$
هواشناسى موثر بر تبخير - تعرق درنظر كرفته مىشود، انتخـاب

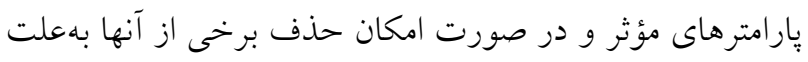

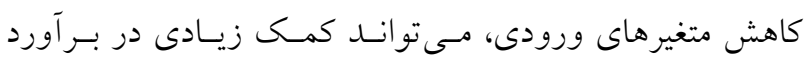

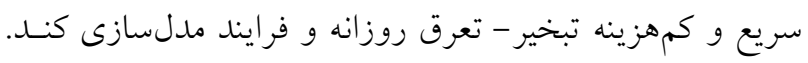

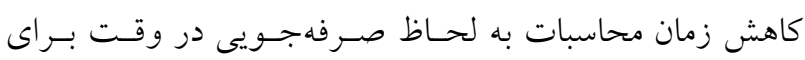

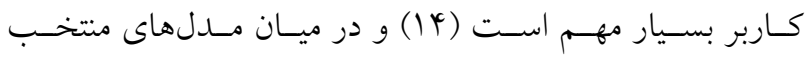

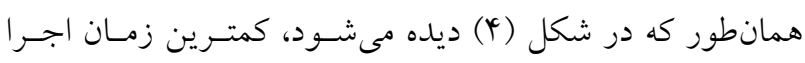

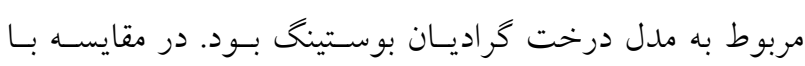

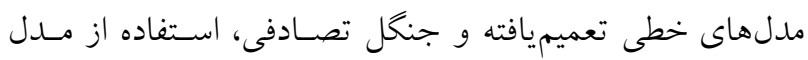

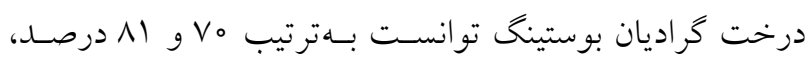
زمان اجراى مدل را كاهش دهد.

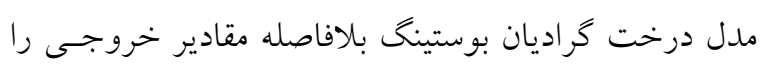

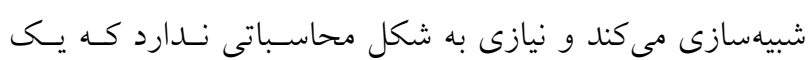

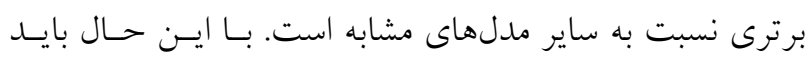

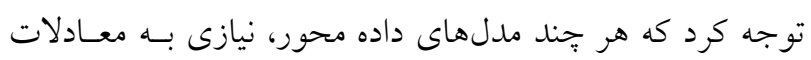

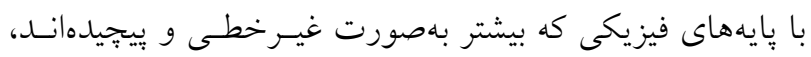

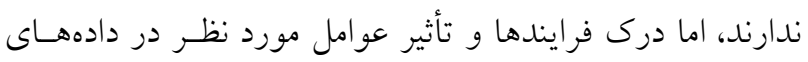

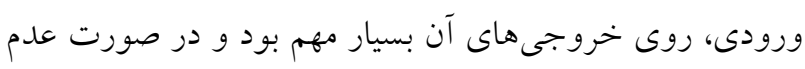

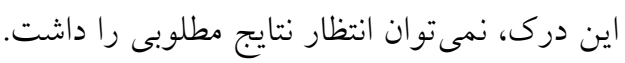
تحليل حساسيت

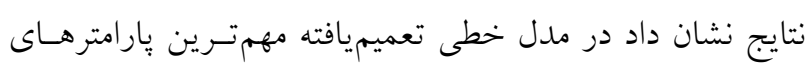

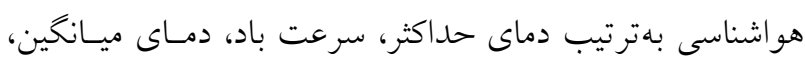

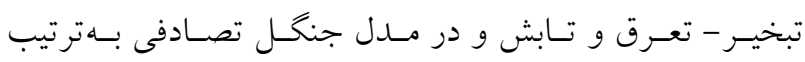

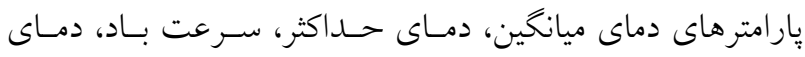

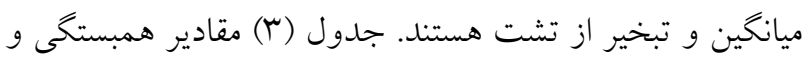

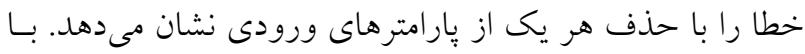

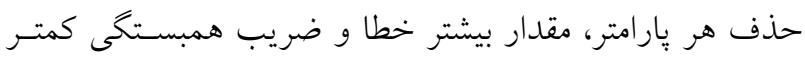

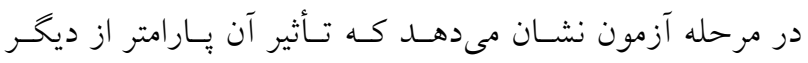

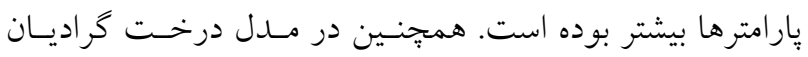

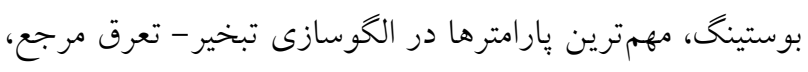

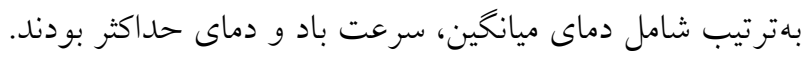




$$
\begin{aligned}
& \text { بوستينگ توانست بهترتيب م. و ا } 1 \text { درصد، زمان اجـراى مــل } \\
& \text { را در مقايسه با مدلهاى خطى تعمسيميافتسه و جنخـل تصـادفى لونى } \\
& \text { كاهش دهد كه از امتيازات ديخر اين روش محسـوب مىشـود. } \\
& \text { همجينين نتايج بهدست آمده نشان داد كه مىتوان مقدار تبخيـر } \\
& \text { تعرق كياه مرجع در منطقه مورد مطالعه را بـا اسـتفاده از تعـداد } \\
& \text { يار امترهاى كمترى نسبت به آنجه در روش فائو - پِنمن - مانتيث } \\
& \text { به كار مىرود، با دقت قابل قبـولى بــــآورد كـرد. از بـين تمـامى }
\end{aligned}
$$

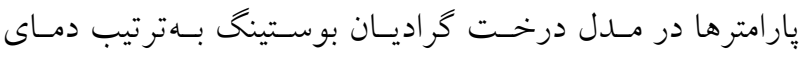

$$
\begin{aligned}
& \text { ميانگين، سرعت باد، دماى حداكثر بيشترين تأثير و اهميت را در } \\
& \text { ميزان تبخير - تعرق روزانـه داشـتند. از ايسنرو اسـتفاده از ايسن } \\
& \text { يارامترها براى تعيين تبخيـر - تعـرق روزانـه توصسيه مسىشـود. } \\
& \text { همجينين با توجه به اهميـت يـارامتر دمـا در الخوهـاى انتخـاب } \\
& \text { شده، ضرورت استفاده از داده هاى با دقت و صسحت مناسـب } \\
& \text { براى اين بارامتر در مدلسازى با روشهاى بيشنهادى ضـرورى } \\
& \text { است. از نتايج يثوهش حاضر مىتوان در بهينهسازى شـبكههاى } \\
& \text { آبيارى و زهكشى و منابع آبى در مناطق خشـى اسـتفاده كـرد. }
\end{aligned}
$$

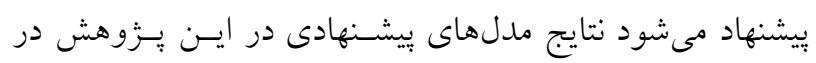

$$
\begin{aligned}
& \text { ساير اقليمهاى كشور ارزيابى شود. }
\end{aligned}
$$

در اين يزوهش دقت مدلهاى خطى تعميميافته، جنگل تصادفى و درخت گراديان بوستينگ در تخمين تبخيـر - تعـرق يتانسـيل روزانه دشت سيستان بررسى شد. در بيشبينى هاى تبخيـر - تعـرق

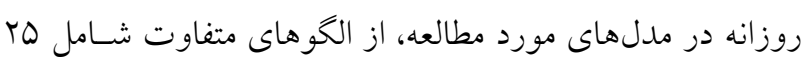

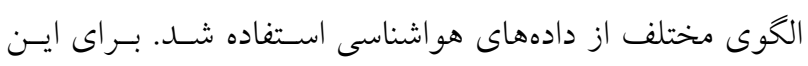
منظور دادههاى دماى حداكثر، دمـاى حـــاقل، دمـاى ميـانخين،

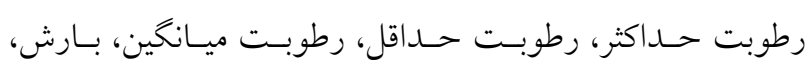

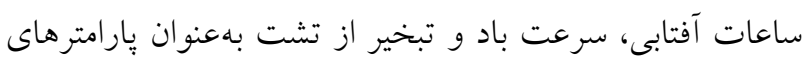

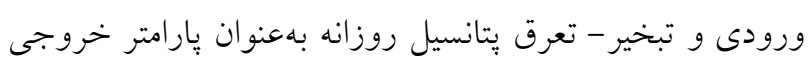

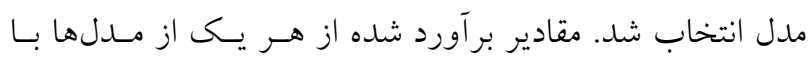
روش فائو - ينمن - مانتيث مقايسه شدند. مدلسازى بـهـصـورت

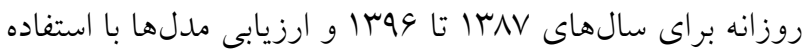
از ضريب همبستخى (R) و مقادير خطاى جذر ميانخين مربعات انجام شد. بررسى نتايج مدلها در ايستشاه نشـان داد كه الخوى MI و مدل درخت گراديان بوستينخ از دقت بالاترى

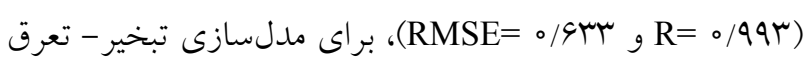
يتانسيل مرجع برخوردارنــــ اسـتفاده از مـــل درخـت كراديـان

منابع مورد استفاده

1. Allen, R. G., L. S. Pereira, D. Raes and M. Smith. 1998. Crop evapotranspiration Guidelines for computing crop water requirements-FAO Irrigation and drainage paper 56. FAO, Rome 300(9): D05109.

2. Breiman, L. 1999. Using adaptive bagging to debias regressions. Technical Report 547, Statistics Dept. UCB.

3. Breiman, L. 2001. Random forests. Machine Learning 45(1): 5-32.

4. Chandler, R. E. and H. S. Wheater. 2002. Analysis of rainfall variability using generalized linear models: a case study from the west of Ireland. Water Resources Research 38(10): 10-1.

5. DehghaniSanij, H., T. Yamamoto and V. Rasiah. 2004. Assessment of evapotranspiration estimation models for use in semi-arid environments. Agricultural Water Management 64(2): 91-106.

6. Diamantopoulou, M., P. Georgiou and D. Papamichail. 2011. Performance evaluation of artificial neural networks in estimating reference evapotranspiration with minimal meteorological data. Global NEST Journal 13(1): 18-27.

7. Dou, X. and Y. Yang. 2018. Evapotranspiration estimation using four different machine learning approaches in different terrestrial ecosystems. Computers and Electronics in Agriculture 148: 95-106.

8. Feng, Y., N. Cui, D. Gong, Q. Zhang and L. Zhao. 2017. Evaluation of random forests and generalized regression neural networks for daily reference evapotranspiration modelling. Agricultural Water Management 193: 163-173.

9. Ferreira, L. B., F. F. Da Cunha, R. A. De Oliveira and E. I. Fernandes Filho. 2019. Estimation of reference evapotranspiration in Brazil with limited meteorological data using ANN and SVM-a new approach. Journal of Hydrology 572: 556-570.

10. Granata, F. 2019. Evapotranspiration evaluation models based on machine learning algorithms-A comparative study. Agricultural Water Management 217: 303-315.

11. Haghighatjou, P. and A. M. AkhondAli. 2008. Computation of evapotranspiration of Sistan plain based on solar data. In: Proceeding of the Second National Conference on Management of Irrigation and Drainage Networks. 
Ahvaz, Iran. (In Farsi).

12. Jabloun, M. and A. Sahli. 2008. Evaluation of FAO-56 methodology for estimating reference evapotranspiration using limited climatic data: application to Tunisia. Agricultural Water Management 95: 707-715.

13. Jain, S., P. Nayak and K. Sudheer. 2008. Models for estimating evapotranspiration using artificial neural networks, and their physical interpretation. Hydrological Processes: An International Journal 22(13): 2225-2234.

14. Keskin, M. E., O. Terzi, E. D. Taylan and D. Küçükyaman. 2009. Meteorological drought analysis using data-driven models for the Lakes District, Turkey. Hydrological Sciences Journal 54(6): 1114-1124.

15. Kişi, Ö. 2009. Modeling monthly evaporation using two different neural computing techniques. Irrigation Science 27(5): 417-430.

16. Koulaian, A., M. A. Gholami Sefidkouhi and M. Ziatabar Ahmadi. 2013. Evaluation of new computational methods on estimation of daily evapotranspiration (Case study: Dasht-e-Naz, Sari). In: Proceeding of the $12^{\text {th }}$ National Conference on Irrigation and Evaporation Reduction. Kerman, Iran. (In Farsi).

17. Luo, Y., S. Traore, X. Lyu, W. Wang, Y. Wang, Y. Xie, X. Jiao and G. Fipps. 2015. Medium range daily reference evapotranspiration forecasting by using ANN and public weather forecasts. Water Resources Management 29(10): 3863-3876.

18. Malohlava, M. and A. Candel. 2018. Gradient boosting machine with $\mathrm{H}_{2} \mathrm{O}$. Available online at: http://docs.h2o.ai/h2o/latest-stable/h2o-docs/data-science/gbm.html .Accessed 24 FEBRUARY 2020.

19. Mattar, M. A., A. A. Alazba, B. Alblewi, B. Gharabaghi and M. A. Yassin. 2016. Evaluating and calibrating reference evapotranspiration models using water balance under hyper-arid environment. Water Resources Management 30: 3745-3767.

20. Mendicino, G. and A. Senatore. 2013. Regionalization of the Hargreaves coefficient for the assessment of distributed reference evapotranspiration in Southern Italy. Journal of Irrigation and Drainage Engineering 139: 349-362.

21. McCullagh, P. 1984. Generalized linear models. European Journal of Operational Research 16(3): $285-292$.

22. Nelder, J. A. and R. J. Baker. 1972. Generalized Linear Models. Wiley Online Library, New Jersey.

23. Nykodym, T., T. Kraljevic, N. Hussami, A. Rao and A. Wang. 2018. Generalized linear modeling with $\mathrm{H}_{2} \mathrm{O}$. Available online at: http://docs.h2o.ai/h2o/latest-stable/h2o-docs/data-science/glm.html .Accessed 24 FEBRUARY 2020.

24. Perera, K. C., A. W. Western, B. Nawarathna and B. George. 2014. Forecasting daily reference evapotranspiration for Australia using numerical weather prediction outputs. Agricultural and Forest Meteorology 194: 50-63.

25. Piri, H. 2012. Assessment of computational methods of estimation of potential evapotranspiration using lysimeter daya (Case study: Sistan plain). Journal of Irrigation and Water Engineering 3(9): 50-62. (In Farsi).

26. Pregibon, D. and T. J. Hastie. 2017. Generalized linear models. In: Statistical Models in S, 195-247. Routledge.

27. Rahimikhoob, A. 2014. Comparison between M5 model tree and neural networks for estimating reference evapotranspiration in an arid environment. Water Resources Management 28(3): 657-669.

28. Rongfan, C., S. Shanlei, C. Haishan and S. Zhou. 2018. Changes in reference evapotranspiration over China during 1960-2012: attributions and relationships with atmospheric circulation. Hydrological Processes 32(19): 3032-3048.

29. Saggi, M. K. and S. Jain. 2019. Reference evapotranspiration estimation and modeling of the Punjab Northern India using deep learning. Computers and Electronics in Agriculture 156: 387-398.

30. Sayyadi, H., A. Oladghaffari, A. Faalian and A. A. Sadraddini. 2009. Comparison of RBF and MLP neural networks performance for estimation of reference crop evapotranspiration. Water and Soil Science 19(1): 1-12. (In Farsi).

31. Snyder, R. L., C. Palmer, M. Orang and M. Anderson. 2009. National weather service reference evapotranspiration forecast. Crop Water Use 4: 1-6.

32. Tabari, H. 2010. Evaluation of reference crop evapotranspiration equations in various climates. Water Resources Management 24(10): 2311-2337.

33. Tabari, H., M. E. Grismer and S. Trajkovic. 2013. Comparative analysis of 31 reference evapotranspiration methods under humid conditions. Irrigation Science 31(2): 107-117.

34. Tabari, H., O. Kisi, A. Ezani and P. H. Talaee. 2012. SVM, ANFIS, regression and climate based models for reference evapotranspiration modeling using limited climatic data in a semi-arid highland environment. Journal of Hydrology 444: 78-89.

35. Tang, D., Y. Feng, D. Gong, W. Hao and N. Cui. 2018. Evaluation of artificial intelligence models for actual crop evapotranspiration modeling in mulched and non-mulched maize croplands. Computers and Electronics in Agriculture 152: 375-384.

36. Traore, S., Y. M. Wang and T. Kerh. 2010. Artificial neural network for modeling reference evapotranspiration complex process in Sudano-Sahelian zone. Water Resources Management 97(5): 707-714.

37. Valipour, M., M. A. Gholami Sefidkouhi and M. Raeini-Sarjaz. 2017. Selecting the best model to estimate potential evapotranspiration with respect to climate change and magnitudes of extreme events. Agricultural Water 
مقايسه عملكرد مدلهاى خطى تعميم يافته، جنگل تصادفى و درخت گر اديان...

Management 180: 50-60.

38. Wen, X., J. Si, Z. He, J. Wu, H. Shao and H. Yu. 2015. Support-Vector-Machine-Based models for modeling daily reference evapotranspiration with limited climatic data in extreme arid regions. Water Resources Management 29: 3195-3209. 


\title{
Comparing of Generalized Linear Models, Random Forest and Gradient Boosting Trees in Estimation of Reference Crop Evapotranspiration (Case Study: The Sistan Plain)
}

\author{
H. Siasar ${ }^{1 *}$, T. Honar ${ }^{2}$ and M. Abdolahipour ${ }^{3}$
}

(Received: December 18-2018; Accepted: July 14-2019)

\begin{abstract}
The estimation of reference crop evapotranspiration (ETo) is one the important factors in hydrological studies, irrigation planning, and water resources management. This study attempts to explore the possibility of predicting this key component using three different methods in the Sistan plain: Generalized Linear Models (GLM), Random Forest (RF) and Gradient Boosting Trees (GBT). The maximum and minimum temperature, mean temperature, maximum and minimum humidity, mean humidity, rainfall, sunshine hours, wind speed, and pan evaporation data were applied for years between 2009 to 2018. Using various networks, the ETo as output parameter was estimated for different scenarios including the combination of daily scale meteorological parameters. In order to evaluate the capabilities of different models, results were compared with the ETo calculated by FAO Penman-Monteith as the standard method. Among studied scenarios, M1 covering the maximum number of input parameters (10 parameters) showed the highest accuracy for GBT model, with the lowest RMSE (0.633) and MAE (0.451) and the maximum coefficient of regression (R = 0.993). Air temperature was found as the most sensitive parameters during sensitivity analysis of studied models. It indicated that accuracy and precision of temperature data can improve the results. Application of the GBT model could decrease the time consumed to run the model by 70\%. Therefore, the GBT model is recommended for estimation of ETo in the Sistan plain.
\end{abstract}

Keywords: FAO Penman-Monteith method, Meteorological parameters, Sensitivity analysis, Air temperature

1. Department of Agriculture, Payame Noor University (PNU), Tehran, Iran.

2. Department of Water Engineering, Faculty of Agriculture, Shiraz University, Shiraz, Iran.

3. Department of Irrigation and Soil Physics, Soil and Water Research Institute, Karaj, Iran.

*: Corresponding Author: Email: hadisiasar@pnu.ac.ir 